\title{
TRABALHO E PRODUÇÃO ASSOCIADA AO TURISMO: TENSÕES E RUPTURAS NO PROCESSO DE CONSTRUÇÃO DA IDENTIDADE DE MULHERES NA COMUNIDADE RURAL CHÃ DE JARDIM
}

\author{
Work and production associated with tourism: tensions and ruptures in the \\ process of constructing the identity of women in the "Chã de Jardim" rural \\ community
}

Josilene Ribeiro de Oliveira'

\begin{abstract}
Resumo
Este artigo traz uma reflexão sobre o trabalho como um valor moral para os sitiantes, em sua articulação com a dinâmica da reciprocidade e a hierarquização das relações sociais. Trata-se de um recorte da tese da autora. 0 objetivo geral é analisar a reinterpretação das práticas de trabalho a partir da participação das mulheres sitiantes no desenvolvimento da oferta turística na cidade de Areia Paraíba. Os dados apresentados foram construídos a partir da etnografia da Comunidade Chã de Jardim e de entrevistas semidirigidas realizadas com 30 sitiantes, entre setembro de 2015 e março de 2016. No plano teórico os interlocutores privilegiados são: Klass Woortmann, Cynthia A. Sarti, Marcos Lanna e Marcel Mauss. Os resultados apontam que as mulheres são protagonistas no trabalho com 0 turismo, ocupando a maioria dos postos e, inclusive, a liderança comunitária, o que Ihes propiciou reconhecimento e elevação da autoestima. Porém, o trabalho das mulheres é percebido e ainda concebido como "ajuda" (complementar), estando subordinado à satisfação e à manutenção da estrutura hierárquica estabelecida. Apesar de não apontar uma ruptura definitiva com o modelo de família tradicional, a experiência de trabalho com o turismo revela a busca de valorização e autonomia das mulheres, bem como as tensões e contradições envolvidas nesse processo.
\end{abstract}

Palavras-chave: mulheres; trabalho; reciprocidade; turismo de base comunitária.

\begin{abstract}
This article to discuss on work as a moral value for the "peasants" [small landowners], in their articulation with the dynamics of reciprocity and the hierarchization of social relations. This paper is based on a doctoral thesis from the same author. The general aim is to analyze the reinterpretation of work practices based on the participation of women 'peasants' in the development of tourism in the city of Areia - state of Paraíba. The data presented were based on the ethnography of the Chã de Jardim community and semi-structured interviews with 30 'peasants' between September 2015 and March 2016. On the theoretical level the privileged interlocutors are: Klass Woortmann, Cynthia Andersen Sarti, Marcos P. D. Lanna and Marcel Mauss. The results indicate that women are protagonists in the
\end{abstract}

\footnotetext{
1 Doutora em Sociologia pela Universidade Federal de Pernambuco (UFPE) e pela Université FranchComté (França). Professora do Depto. de Comunicação da Universidade Federal da Paraíba (UFPB), João Pessoa, Brasil. E-mail: josilene.ro2011@gmail.com
} 
work with tourism, occupying most positions and even the community leadership, which has allowed them to have more social recognition and raise self-esteem. However, the work of women is perceived and still conceived as "help" (complementary), being subordinated to the satisfaction of the family and maintenance of the hierarchical structures established. Although it does not indicate a definitive rupture with the family peasant structure, the experience of working with tourism reveals the search for valorization and autonomy of women, as well as the tensions and contradictions involved in this process.

Keywords: women; work; reciprocity; community based tourism.

\section{INTRODUÇÃO}

Localizada na microrregião do brejo paraibano, na região Agreste desse estado nordestino, a Chã de Jardim é uma comunidade rural de cerca de 352 habitantes, que está envolvida diretamente na produção da oferta turística no municipio de Areia, na Paraiba. Essa cidade, que já foi considerada, nos séculos XIX e até o início do século XX, de "celeiro do sertão", pelo cultivo e fornecimento de vários gêneros alimentícios (ALMEIDA, 1980), é hoje um dos principais destinos turísticos do interior do estado. Areia recebe além do rescaldo do fluxo turístico do Maior São João do Mundo, em Campina Grande/PB, durante o período dos festejos juninos, dada sua proximidade (aproximadamente $50 \mathrm{Km}$ ) da referida cidade, um fluxo regular de excursionistas e visitantes, em função de seu patrimônio cultural, paisagístico e arquitetônico, cujos engenhos, na área rural, o Parque Estadual Mata Pau Ferro e os museus e casarões históricos (tombados pelo Iphan desde 2006) na sede do município são exemplos. 
Figura 01: Mapa localização Areia e seus distritos

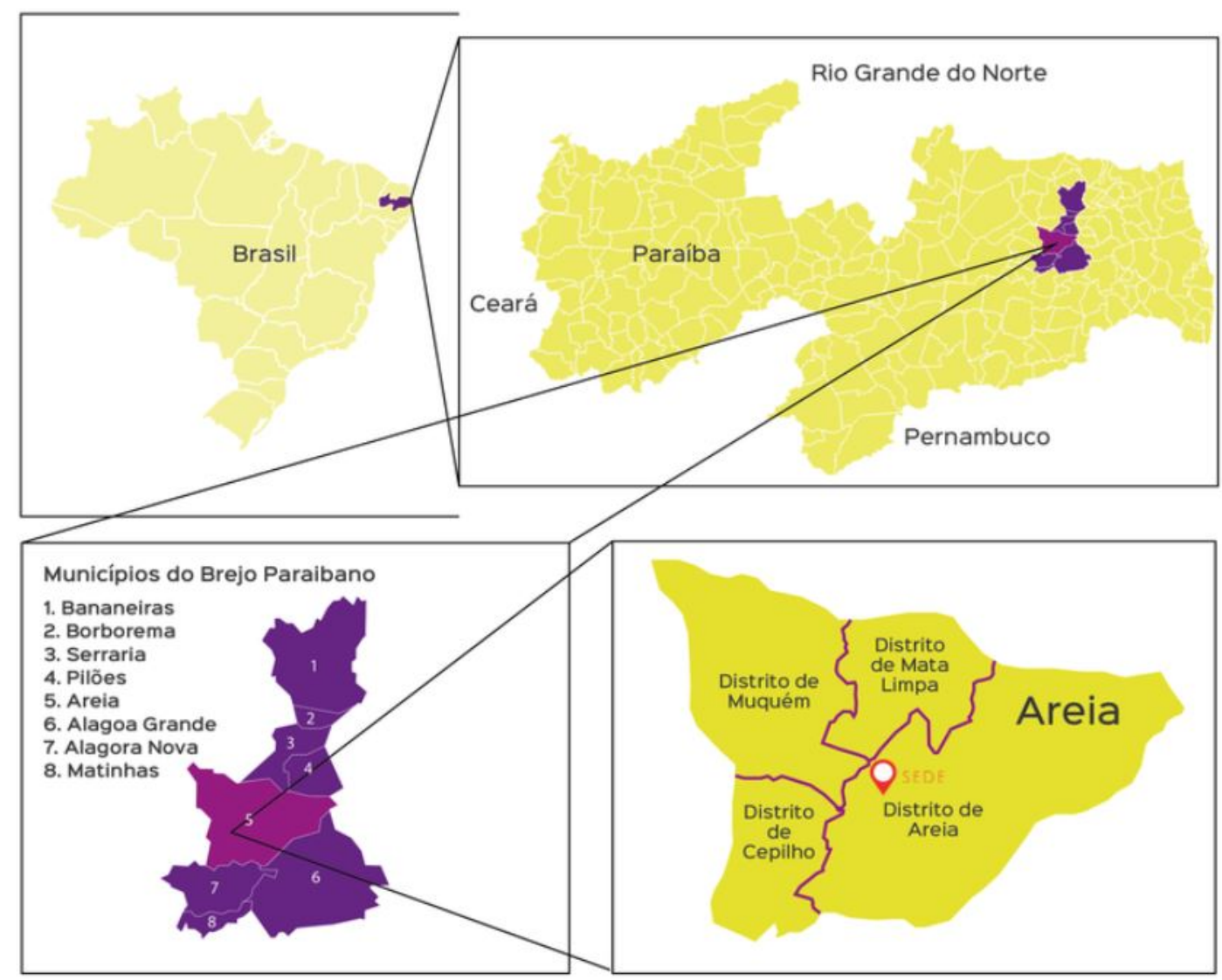

Município: Areia; Latitude: $06^{\circ} 57^{\prime} 48^{\prime \prime}$ S; Longitude: $35^{\circ} 41^{\prime} 30^{\prime \prime}$ W; Altitude: 618m; Área: 266,596 km² Fonte: IBGE - Instituto Brasileiro de Geografia e Estatistica

Fonte: Dados do IBGE, 2017. Produzido por Rinker Cabral, 2017.

Os sitiantes da Chã de Jardim participam da oferta turística do município de Areia por meio da comercialização de serviços concebidos e gerenciados por eles mesmos. Esses serviços compreendem: o Restaurante Rural Vó Maria, que oferece exclusivamente pratos "tradicionais"; uma loja/comércio, onde são vendidos, além de guloseimas e de "produtos da região" (cachaças, rapadura etc.), as peças de artesanato produzidas por mulheres da comunidade; as trilhas guiadas e vivências na Reserva Mata Pau Ferro, em frente da qual fica o restaurante; e, mais recentemente, um camping, chamado de Hotel de Barracas, que passou a funcionar em dezembro de 2017. A comercialização de tais atividades, propostas e organizadas pelo grupo a frente da Associação para o Desenvolvimento Sustentável da Chã do Jardim (Adesco), gera aproximadamente 30 postos de trabalho diretos, aos quais apenas os participantes daquilo que denomino microssistema ou circuito de circulação de dádivas têm acesso. É efetivamente 
por meio desse microssistema que ocorre a circulação dos rendimentos provenientes da produção associada ao turismo, concebidos como dádivas, redistribuidas hierarquicamente.

Figura 02: Núcleo da Comunidade Chã de Jardim e adjacências

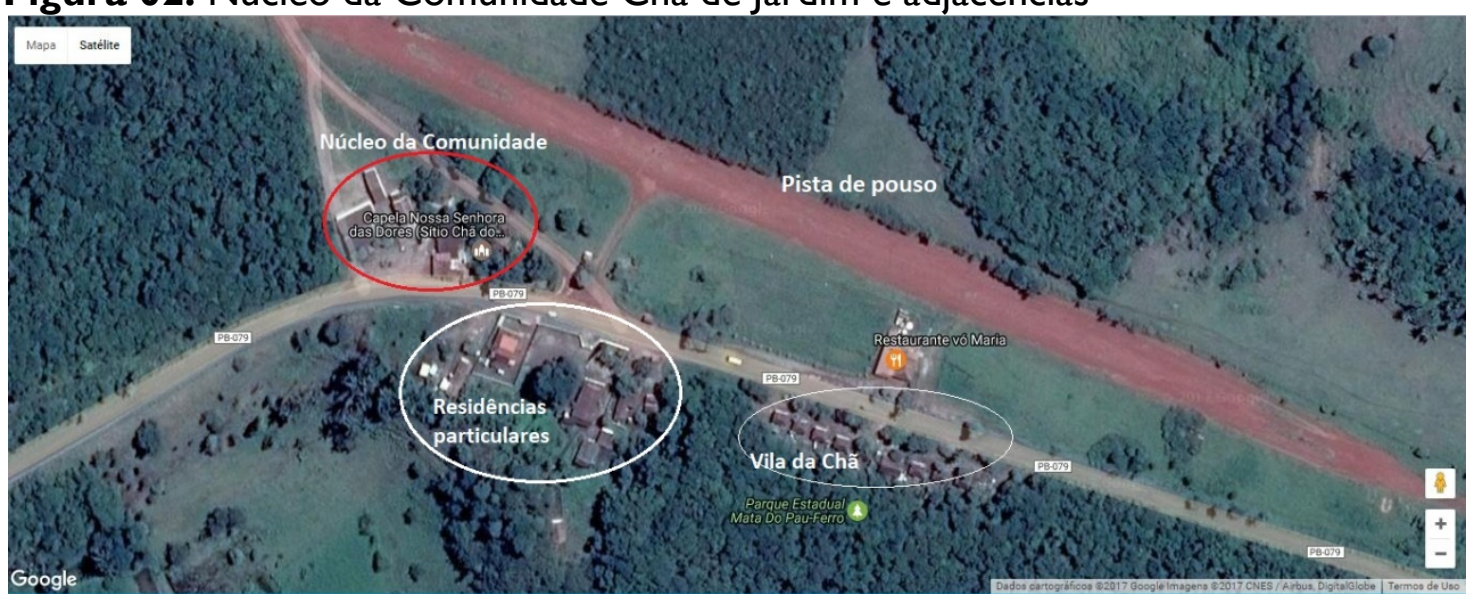

Fonte: Google Maps com adaptações feitas por Josilene Ribeiro, 2017.

Resultante de um processo de construção simbólica recente ${ }^{2}$, que permitiu parte dos sitiantes residentes no Sítio Chã do Jardim, Sítio Jardim, Sitio Olho d'Água Seco, Lameiro, Fazenda Riachão e Fazenda Bujarỉ se autoproclamarem membros de uma só comunidade, a Chã de Jardim pode ser entendida como uma comunidade de interesses, formada tanto pela aparente convergência entre as vontades do lider e dos liderados, como pela identidade cultural de seus membros, que se auto-definem como "povos dos sitios".

\footnotetext{
2 Adotando uma abordagem histórica, verificou-se que a unificação dessas seis localidades como parte de uma só comunidade é datada e relativamente recente, sendo motivo de certa controvérsia, por causa da persistência e do uso concomitante de duas identidades e territorialidades justapostas: Chã do Jardim e Chã de Jardim. Ao que tudo indica, após a criação da Associação para o Desenvolvimento Sustentável da Chã do Jardim, os próprios sócios, que ulteriormente tornaram-se responsáveis pelo desenvolvimento da oferta turística, começaram a usar a expressão "Comunidade Chã de Jardim" no âmbito da Associação. O termo parece que já era empregado pelo Grupo de Jovens a União Faz a Força, ligado à Capela/Igreja católica local, do qual emergiu a atual líder comunitária e proprietária do Restaurante Vó Maria (RVM). Ao apropriar-se dessa identidade, a Associação tira disso uma vantagem estratégica na promoção dos atrativos turísticos locais, enquanto a Igreja usa a denominação 'comunidade' para promover a união dos sitiantes em volta das atividades religiosas organizadas pelo Grupo de Jovens. Tanto em um caso como em outro, a adoção da denominação "Comunidade Chã de Jardim" designa uma construção simbólica, que pode ser interpretada como fruto do desejo de marcar os limites simbólicos entre "eles" (os de fora) e "nós" (os de dentro) e, logo, de estabelecer e manter "fronteiras identitárias" (CUCHE, 2002).

3 As duas últimas localidades - as fazendas - são propriedades privadas, demarcadas por cercamento, uma voltada para avicultura e outra, predominantemente, para o cultivo de cana de açúcar. Já no caso dos sitiantes, a ausência de cercamento indica o uso compartilhado de cacimbas e outras fontes de água, além de outros bens comunitários. Do ponto de vista político-administrativo, os sítios referidos como pertencentes à Comunidade Chã de Jardim estão subordinados ao Distrito de Muquém (Moquém), onde há um povoado de mesmo nome.
} 
De fato, "o sítio" (diferente "da rua", reconhecida como o "lugar do citadino", e da fazenda, "lugar do fazendeiro"), enquanto patrimônio da família, parece ser a unidade elementar a partir da qual os sitiantes organizam as relações sociais, o trabalho e definem seu modo de vida (HEREDIA, 1979; WOORTMANN, 1983; WOORTMANN, 1990; PALMEIRA, 2009). Razão por que, seguindo os passos dos pesquisadores do Museu Nacional ${ }^{4}$, optei por usar essa categoria em detrimento de camponês ou agricultor familiar para designar os sujeitos pesquisados. Além disso, é preciso ter claro que muitos sitiantes abandonaram há algum tempo a agricultura, outros a tornaram atividade secundária, assalariando-se, passando a exercer atividades profissionais fora do domicílio rural e, em vários casos, trabalhando exclusivamente como servidores públicos, professores, motoristas, comerciantes etc., o que não os impediu de continuar morando e desenvolvendo suas práticas religiosas e valores tradicionais, ainda que estes tenham sofrido significativas mudanças.

O uso da expressão "comunidade" para o conjunto das seis localidades mencionadas reporta-se, assim, a um processo de construção de sentidos, que permite pensar os fatores de integração do território e dos sitiantes a partir de valores e visões de mundo compartilhadas. Identificaram-se quatro fatores que colaboram para o sentido de unidade do território: 1) os laços de parentesco entre moradores de fazendas e sítios próximos; 2) as práticas de sociabilidade e as atividades lúdico-religiosas organizadas a partir da Capela de Nossa Senhora das Dores, localizada no Sítio Chã do Jardim, que pode ser considerado o núcleo da vida comunitária; 3) a adesão ao princípio da reciprocidade, o qual rege as relações familiares e comunitárias; 4) a criação do "Grupo de Jovens a União Faz a Força" e da Associação para o Desenvolvimento Sustentável da Chã do Jardim (Adesco).

Nos últimos anos, o trabalho agrícola e não agrícola dos sitiantes passou a ser associado à atividade turística: alguns agricultores familiares

\footnotetext{
4 Diversos pesquisadores do meio rural nordestino, vinculados ao Programa de Pós-Graduação em Antropologia Social do Museu Nacional do Rio de Janeiro, tais como Moacir Palmeira (2009), Beatriz Heredia (1979 e 1988), Lygia Sigaud $(1979,1996)$, Afrânio Garcia $(1989,2017)$, além de Ellen Woortmann $(1983,1997)$ e Klass Woortmann $(1987,1990)$, dentre outros, utilizam o termo sitiante para designar seus interlocutores principais.
} 
fornecem insumos para o Restaurante, como frutas, tubérculos, verduras, grãos e galináceos; um grupo de mulheres foi criado pela líder e produz peças de artesanato na folha da bananeira, as quais são comercializadas na loja ou Budega $^{5}$ do Restaurante Vó Maria (que nominarei também pelo acrônimo RVM), ao lado do estabelecimento; a Adesco, responsável pela unidade de processamento de polpas de frutas que abastecem o RVM e que são comercializadas $^{6}$ diretamente com as escolas públicas, pelo Programa Nacional de Alimentação Escolar (PNAE).

Criado em 2013, o Restaurante é o empreendimento catalisador de todos os esforços, pois para ele convergem e a partir dele são planejados os demais serviços oferecidos, atualmente pelos sitiantes. Construído com financiamento parcial (aproximadamente 50\%) do Programa Nacional do Fortalecimento da Agricultura Familiar, o RVM localiza-se às margens da PB079, em frente à Reserva Estadual Mata Pau Ferro, onde alguns sitiantes já prestavam serviços de condutores às escolas e visitantes interessados em fazer trilhas no local, desde o início dos anos 2000. Com base nos dados fornecidos pela administração do Restaurante, frequentaram o estabelecimento, em média, 1.745 comensais por mês ${ }^{7}$, no ano de 2015, registrando-se um aumento de aproximadamente 10\% no ano de 2016.

O engajamento direto dos sitiantes, especialmente das mulheres, e o envolvimento indireto de outros membros da comunidade justificam o uso do conceito de turismo de base comunitária para designar as atividades

\footnotetext{
5 Por definição, o termo bodega significa "coisa imprestável ou malfeita" (DICIONÁRIO CALDAS AULETE, 2004, p. 108). Popular no Nordeste brasileiro, o termo budega ou bodega é empregado para designar uma pequena mercearia de aparência precária devido a falta de organização e/ou espaço, onde se vende e se consome, tradicionalmente, a cachaça e outras bebidas baratas, além de gêneros alimentícios básicos, como grãos e enlatados. Atribui-se a origem da palavra budega ao espanhol bodega, que significa um porão, loja ou depósito onde se vende vinho a retalho. O uso do termo dentro da oferta turística na Chã de Jardim pretende retomar o uso popular da palavra - que, de fato, fazia parte do cotidiano dos sitiantes-, para ressaltar o caráter tradicional e a suposta autenticidade da proposta turística face aos visitantes.

6 Aprovada em 2009, a Lei federal 11.947 dispõe sobre o atendimento da alimentação escolar e possibilitou a aquisição direta de produtos oriundos da agricultura familiar pelo Programa Nacional de Alimentação Escolar (PNAE), estipulando que no mínimo 30\% do total dos recursos financeiros repassados pelo Governo Federal aos estados e municípios deverão ser utilizados na aquisição de gêneros alimentícios diretamente da agricultura familiar (BRASIL, 2017).

7 Em 2015, no total foram atendidos 20.942 comensais (refeições servidas), se considerarmos o aumento anual de $10 \%$ sobre esse total, ele se torna bem próximo ao total da população de Areia, estimada pelo IBGE em 22.776 pessoas, no ano de 2017. Deve-se acrescentar que as refeições servidas a crianças menores de cinco anos não são contabilizadas nesse total, pois não são cobradas, conforme informações da administração do restaurante.
} 
turísticas realizadas na Comunidade. As mulheres ocupam 63,3\% dos postos de trabalho direto e também estão implicadas na maior parte das atividades indiretas. Para as artesãs, por exemplo, o trabalho com o artesanato agregou autoestima e reconhecimento dentro e fora da comunidade, resultando em uma identidade positiva. É certo que diferentes formas de trabalho e saberes tradicionais convivem com inovações no âmbito da produção associada ao turismo, possibilitando o diálogo entre diferentes saberes e gerações de sitiantes. O saber tradicional das anciãs, por exemplo, é importante na produção do artesanato e no preparo de pratos tradicionais servidos aos clientes que frequentam o RVM. No entanto, é o conhecimento formal (via escolarização) que possibilitou a transformação de saberes tradicionais e bens em produtos simbólico-culturais modernos pela liderança.

Além disso, constatou-se que o conhecimento tradicional dos sitiantes anciãos tem um "valor menor", sendo remunerado de modo inferior ao saber qualificado dos jovens. Ocorre que, graça à posse de maior capital escolar e à "capacidade" de compreender as demandas dos visitantes, os jovens sitiantes são os beneficiários diretos do processo, assumindo a condição de protagonistas e percebendo rendimentos mais elevados, além de se situarem mais próximo do núcleo do microssistema de circulação de dádivas, ou seja, da liderança. Essa situação denota que a hierarquização das relações sociais é um outro elemento estruturante desse microssistema, traduzindo-se em remunerações diferentes conforme o tipo de vínculo.

Nesse contexto, pergunta-se: como o trabalho das mulheres dentro da experiência de produção da oferta turística contribui para a reconfiguração dos valores camponeses e a reconstrução identitária das sitiantes? Quais os impactos e as particularidades do trabalho e da liderança feminina sob o conjunto das relações comunitárias?

Ao tentar responder essas questões empiricamente, três aspectos sobressaem-se: o trabalho como elemento mediador das relações humanas, pelo qual se constroem vínculos e se estabelece alianças; trabalho como um valor moral, pelo qual os sitiantes procuram afirmar sua autonomia e 
dignidade, obter respeito e reconhecimento social e, nesse caso, poderia ser interpretado como um instrumento de lutas simbólicas pelo qual os agentes tentam melhorar seu status dentro do próprio grupo e ascender socialmente; trabalho como uma dádiva - transfigurando-se em serviços de hospitalidade e alimentação, por exemplo -, que segue junto com a coisa produzida, “obrigando" aquele que reconhece esse dom e o recebe a fazer uma contraprestação, um gesto de retribuição.

A discussão está organizada em três tópicos: Trabalho na ordem moral campesina, em que trato das interações entre os valores "trabalho", "família", "religião" e "terra"; Divisão sexual do trabalho, hierarquia e papéis de gênero, onde procuro verificar como os papeis e os valores masculino e feminino estão implicados na divisão sexual do trabalho dentro da família e como isso se reflete na atividade do turismo; e Trabalho para as artesãs: tecendo saberes, identidades e redes de sociabilidade, em que trato dos significados do trabalho para as artesãs.

Quanto à opção por realizar um estudo etnográfico da comunidade rural, trata-se de uma estratégia de construção dos dados motivada pela necessidade de imersão no mundo dos pesquisados, que, simultaneamente, se revelou para mim "um potente instrumento de autoconhecimento através do conhecimento íntimo do outro e, por isso, um meio para a auto-aceitação" (WACQUANT, 2006, p. 26), posto que minha própria trajetória de vida seja atravessada pelo deslocamento geográfico e social do campo para cidade.

Nesse sentido, meu primeiro desafio foi fazer um "esboço de autoanálise”, estratégia por meio da qual reconstituí minha trajetória de sitiante a citadina, de aluna à professora-pesquisadora; e pude reconhecer as origens dos sentimentos ambíguos que eu nutria em relação ao território rural, para poder, em seguida, afastar as pré-noções e os preconceitos dirigidos às práticas culturais de seus habitantes. Ademais, privilegiando a metodologia qualitativa, o uso da etnografia proporcionou unidade ao conjunto dos dados coletados - concebendo-os como "textos" que se articulam no processo de construção de "teias densas de significados", das quais fala Geertz (2008) -, permitindo uma interpretação dialética entre as categorias nativas e analíticas, identificadas a partir da observação do uso da linguagem e das 
pequenas ações cotidianas dos agentes, assim como da análise desse material pela pesquisadora. Observação entendida aqui como recurso para flagrar o uso de representações, memórias e formas de classificação para definir a si mesmos e aos outros (JUNIOR; HASEGAWA, 2017).

O processo de pesquisa de campo na comunidade teve início em setembro de 2015 e se estendeu até março de 2016. Durante esse período estabeleci residência na Chã do Jardim, graça a uma oferta da líder comunitária, na "casa de apoio" de uma de suas irmãs, que se localiza exatamente em frente ao Restaurante Vó Maria e ao lado do Parque Estadual Mata Pau Ferro. A proximidade estabelecida pelo contato com a líder trouxe algum risco para pesquisa, sobretudo porque fui tomada por membro de sua família, por alguns sitiantes. O inconveniente dessa relação de proximidade foi minimizado pela minha inserção nas atividades religiosas, meio pelo qual assegurei minha independência na escolha dos entrevistados e pela decisão de ir ao encontro destes sempre sozinha, evitando gerar comentários sobre as entrevistas.

A fase de entrevistas na comunidade teve início em janeiro de 2016, abordando primeiramente as artesãs e os idosos, deixando deliberadamente os trabalhadores do RVM para um segundo momento, pois sabia que estes últimos conversariam entre si sobre a entrevista e isso poderia interferir no material coletado. Essa escolha revelou-se bastante adequada, pois me deu oportunidade de adaptar o roteiro de entrevista e a linguagem para aproximar a interação de uma conversação, incluindo, por exemplo, um espaço final para que a pessoa falasse livremente sobre o que desejasse, sem perguntas, o que rendeu um rico material do qual me servi, sobretudo no caso das artesãs.

Por mais amistosa que eu tenha tentado ser, o fato de ser uma "pesquisadora da universidade" causou desconforto para alguns sitiantes entrevistados, que ficou perceptivel na postura corporal, no desvio de olhar e em suas falas hesitantes - procurando me agradar. Outra atitude comum era desculpar-se, ao final da entrevista, por "não saber falar direito". Os mais idosos, muitas vezes, ao final da conversa, agradeciam por ir entrevistá-los e 
Trabalho e produção associada ao turismo | Josilene Ribeiro de Oliveira

às vezes fizeram questão de me presentear com algo (jaca, peças de artesanato, muda de flores etc.), em uma clara tentativa de construir uma relação duradoura pela troca de dons. Isso porque, conforme apreendi, ir ao encontro dos sitiantes, ainda mais no caso das artesãs, e dedicar-lhes tempo para ouvir suas histórias de vida significava que elas e o que tinham para falar era importante para mim, sendo isso interpretado como um gesto de reconhecimento - um dom, que deveria ser retribuído de alguma maneira, o que explica os "presentes" que me foram ofertados.

\section{TRABALHO NA ORDEM MORAL CAMPONESA}

"Trabalho" é uma das categorias nucleares da campesinidade e que está intrinsecamente ligada, de modo relacional, às categorias "família", religião e "terra", segundo o conceito de Klass Woortmann. Para esse autor, entre os camponeses, "não se pensa o trabalho sem pensar a terra e a família” (WOORTMANN, 1990, p. 23). Segundo Woortmann (1990), dentro da ética camponesa, o trabalho é um valor moral associado à honra e à hierarquia. Tornando-se um dos instrumentos fundamentais da afirmação pessoal e social dos indivíduos, o valor-trabalho contrapõem-se à noção abstrata de trabalho como mercadoria, concebido quantitativamente em função do princípio da produtividade (SARTI, 1994). De fato, para muitos sitiantes, o trabalho é tanto mais honrado quanto mais árduo ou sacrificado for. No entanto, tal percepção contrasta diretamente com a compreensão moderna de que o trabalho intelectual (que implica conhecimento, disciplina e qualificação) tem mais valor e deva ser melhor remunerado. Compreensão esta que é adotada e aplicada pelos jovens sitiantes na redistribuição dos rendimentos resultantes da produção da oferta turística. E talvez este seja um dos pontos mais conflituosos para os envolvidos nessa atividade, pois eles também entendem o trabalho como um sacrifício pelo qual o homem atesta sua dignidade. Assim, "o valor do trabalho se define dentro de uma lógica em que conta não apenas o cálculo econômico, mas o benefício moral que retiram desta atividade" (SARTI, 1994, p. 122).

Esse beneficio moral está relacionado ao fato do trabalho proporcionar e viabilizar relações fundamentais, tais como aquelas que ocorrem dentro da 
família, que, na área pesquisada, é, primeiramente, concebida por 'laços de sangue', secundariamente, por meio de rituais religiosos, e sempre com base na dinâmica da reciprocidade e de forma hierarquizada. Vale ressaltar que tais relações dão sentido a família, ao mesmo tempo em que "provêem" o sentido do trabalho (SARTI, 1994).

\section{Ressignificando a identidade e os valores camponeses pelo trabalho não agrícola}

$\mathrm{Na}$ área estudada por mim, o trabalho é um valor nuclear da vida dos sitiantes - em sua maioria, praticantes do catolicismo -, inserindo-se na dinâmica da dádiva, ela própria base da relação com Deus e com a terra. Todavia, no catolicismo, o trabalho aparece como uma sentença condenatória de Deus para os homens. Conforme os preceitos bíblicos seguidos pela religião católica, é com fadiga e sacrifício que o homem deve obter o alimento de que necessita (BÍBLIA: Gênesis 3, p. 17-19). De acordo com o livro do Gênesis, no Velho testamento, o trabalho é imputado por Deus ao homem, como um castigo por seu pecado original. Assim, o trabalho aparece como um sacrificio para "os homens", que após serem expulsos do Jardim do Éden, precisam cultivar a terra para dela obter o alimento diário necessário a manutenção da vida. Nessa mesma lógica, a terra é concebida como grande provedora e uma dádiva dada por Deus ao homem. A relação com Deus, por sua vez, é a fonte que alimenta a cadeia de relações de obrigações morais, a qual o homem está submetido (SARTI, 1994).

A noção de sacrificio como forma de estabelecer e/ou reatar uma aliança com Deus é importante para os sitiantes. No catolicismo, o próprio Cristo seria o exemplo supremo de sacrificio, posto que tivesse dado sua vida para salvar a humanidade do pecado, reconstituindo uma aliança dos homens com Deus. A morte de Cristo na cruz é o principal símbolo do catolicismo, estando presente em diversos rituais, imagens e símbolos da religião. Está implícito no ato de Cristo - narrado tanto no Velho como no Novo Testamento e em diversas passagens bíblicas -, a ideia de que para estabelecer uma aliança é preciso algum tipo de sacrificio de ambas as partes. Segundo tal narrativa, ratificada nos principios do catolicismo, é preciso efetuar nem que seja simbolicamente uma "troca", como no caso dos 
Trabalho e produção associada ao turismo | Josilene Ribeiro de Oliveira

pagadores de promessas que depositam ex-votos (que simbolizam a parte do corpo curada) em capelas e santuários ou se auto-flagelam como forma de "retribuir" e quitar sua "divida" com o santo que os agraciou. O trabalho pode, nesse sentido, ser interpretado como uma forma de sacrifício e um dom, que é realizado em "troca" ou em retribuição a outro dom. Em sendo uma dádiva, o trabalho seguiria, simbolicamente, junto com a coisa produzida, obrigando o portador do bem a uma contraprestação (MAUSS, 2003).

Verificou-se que, diferente do sentido de adiamento da satisfação que está presente na noção de trabalho ascético para o protestantismo, analisado por Weber (1987), em A ética protestante e o espírito do capitalismo $0^{8}$, apesar de trabalhar ser um sacrifício para os sitiantes, o trabalho também é motivo de alegria porque viabiliza as relações familiares, a troca de dons e reafirmar sua identidade. "Alegria" que, para os jovens sitiantes engajados nas atividades turísticas, advém da oportunidade de "estar juntos", celebrar suas crenças e reafirmar os laços com a comunidade de interesses da qual fazem parte; "alegria" que se transforma em orgulho pelo reconhecimento social que eles vêm obtendo graças ao trabalho “sacrificado". Logo, reconhecimento que recompensa o sacrificio.

A categoria reconhecimento é mobilizada e mencionada pelos sitiantes quando falam da relação com os turistas e visitantes e da aparição da comunidade na mídia, dando a entender que se trata de um reconhecimento por outros grupos sociais, que não fazem parte da hierarquia interna da comunidade. Por outro lado, dentro do microcosmo da comunidade, observouse que ser um "trabalhador" é uma qualidade moral, porque para os sitiantes designa uma posição e uma forma honrada de viver no mundo, por oposição a condição de "vagabundo" - desprezado segundo a ética cristã que outorgou ao trabalho um caráter ascético.

\footnotetext{
8 Nessa obra, cuja primeira edição brasileira foi publicada em 1967, Max Weber (1987) afirma que, dentre os grupos protestantes, o calvinismo foi o primeiro a introduzir na ética cristã o trabalho como uma vocação designada por Deus e por meio da qual o ser humano alcança virtude e preserva sua fé, mortificando seu corpo no trabalho diário. De acordo Weber (1987), o protestantismo e dentro dele alguns ramos - calvinismo, pietismo, metodismo e algumas seitas batistas -, por causa de sua fé e da ética que praticavam, deram uma importante contribuição para a formação do espírito que impulsiona a economia ocidental, favorecendo a formação do regime capitalista. Com base em análises estatísticas realizadas a partir de dados de algumas regiões da Alemanha, o referido autor observa que os católicos têm menor impulso aquisitivo, preferindo levar uma vida tranquila e segura, ao contrário dos protestantes.
} 
Em sentido clássico, a produção de alimentos e o trabalho com a terra caracterizam a identidade camponesa. De acordo com Woortmann (1990, p. 62), para os camponeses, "o trabalho é aquilo que transforma a terra de Deus em patrimônio da família", sugerindo uma forte correlação entre os valores trabalho, religião, terra e família. Os estudos brasileiros e franceses sobre campesinato argumentam que a família camponesa guia-se pela necessidade de perpetuar a unidade do grupo e manter o patrimônio familiar - a terra, levando os filhos desde a infância a assimilar esse valor e a contribuir para esse fim (GUIGOU, 1968; MENDRAS, 1976). Assim a terra seria apreendida não como uma mercadoria, como uma "propriedade", no sentido capitalista, mas, sim, como um valor porque nela se realiza o trabalho que permite a perpetuação da família. Trata-se, pois, de uma relação de interdependência, em que "só é legitima a posse [da terra] porque baseada no seu trabalho" (MARTINS, 1982 p. 61).

A família camponesa configura-se como uma comunidade de interesses, afetos e conflitos, que não separa produção/trabalho e moradia, caracterizando-se pela organização do trabalho no interior do grupo doméstico (WOLF, 1970; CHAYANOV, 1985; MENDRAS, 1976) e constituindo uma unidade indivisivel, cujo alicerce material seria a terra. Nas palavras de Woortmann (1990, p. 62):

Sendo a terra "aquilo que passa do pai para o filho" (sentido original do termo patrimônio), e não pertencendo nem ao pai nem ao filho, mas ao todo expresso pela família, é o patrimônio que materializa a honra da família, mais notadamente da Casa, que constitui ponto de honra para o pai.

As relações sociais e familiares dentro da Comunidade Chã de Jardim se expressam em termos de obrigações morais, em que os membros devem sempre retribuir o dom recebido. No Ensaio sobre a dádiva, Marcel Mauss (2003) esboça uma "teoria da obrigação", expressa da seguinte forma: para em um futuro receber, é preciso dar no presente; por sua vez, receber implica em retribuir, em um futuro próximo. De acordo com Mauss (2003), o ciclo da dádiva implica em reciprocidade, constituindo uma relação reversivel entre sujeitos morais, que conjuga gratuidade de dons e incerteza de retorno, com vista a criar, manter ou reproduzir alianças e a sociabilidade 
do grupo (SABOURIN, 1999). Na Comunidade, verifica-se que a dinâmica da reciprocidade, bem como o respeito ao intervalo entre dar, receber $\mathrm{e}$ retribuir, encontra fundamento nos preceitos morais cristãos, traduzidos objetivamente nas práticas religiosas, que estão intrinsecamente ligadas à sociabilidade dos sitiantes, sendo, portanto, definidoras da campesinidade.

Ao tencionar os dados empíricos levantados junto aos sitiantes, face aqueles apresentados por Woortmann $(1987,1990)$, Pongratz (1990) e Sarti (1994), é possivel pensar que o princípio da reciprocidade incorpora-se ao habitus $^{9}$ dos sitiantes como um princípio moral que os acompanha, mesmo em lugares distantes de sua origem, ganhando forma na relação entre trabalho, casa, família e comunidade. Assim, a honra se realizada no patrimônio-casa, lócus por excelência da família, razão porque ter uma casa é motivo de grande orgulho entre as classes populares. Por sua vez, a respeitabilidade da família e a honorabilidade precisam ser "provadas", isto é, atestadas pelo "trabalho honesto" e referendadas nas relações comunitárias, traduzindo-se em códigos comuns de visão e divisão de mundo, que estão correlacionados as posições ocupadas pelos indivíduos e suas famílias no espaço social.

Ressalto que apesar dos territórios rurais não mais se definirem exclusivamente pelo trabalho agrícola - mas sim pela pluriatividade e pela multifuncionalidade, estou certa que o "valor-terra" não deixou de ser importante para sitiantes e para ex-sitiantes. Porém, "terra" e "espaço rural" são categorias muito abstratas e distantes para os pesquisados, as quais ganham sentido apenas quando referidas a um espaço concreto: o sitio, lugar do trabalho por excelência e resultante do trabalho porque um espaço construído (WOORTMANN, 1983; WOORTMANN, 1997). O sítio também simboliza e viabiliza um conjunto de relações comunitárias, que dão origem a laços afetivos e ao sentimento de pertencimento.

Relações de partilha e de cooperação, que outrora se realizavam entre as mulheres e as famílias da comunidade estudada por meio da ajuda

\footnotetext{
9 De acordo com Bourdieu (2001) o habitus define-se por um sistema de disposições incorporadas capaz de atualizar-se e aprender, através da aquisição e acúmulo de capital cultural ao longo da socialização secundária do individuo. Por fim, o agente torna-se capaz de inventar meios novos de desempenhar antigas funções diante situações novas.
} 
mútua na produção de alimentos, na troca simbólica de crianças por meio do apadrinhamento, dos encontros e diálogos ocorridos em espaços como as cacimbas, estão sendo reconstruídas e recuperadas no trabalho comunitário em prol da Igreja/Capela local. A Capela dedicada à Nossa Senhora das Dores é atualmente o principal espaço de sociabilidade e de encontros dos sitiantes, em geral. A organização de festas e atividades lúdico-religiosas na Capela é efetivamente um meio para manter a coesão social entre os sitiantes. Entretanto, a gestão da vida comunitária, incluindo as atividades lúdico-religiosas, é planejada e realizada pelos trabalhadores da Adesco e do Restaurante Vó Maria, que juntos formam o núcleo gestor da Comunidade. De tal forma que as atividades comerciais desenvolvidas nesses espaços conexos não são dissociadas das atividades religiosas e culturais da comunidade, na visão dos trabalhadores. Em outras palavras, o trabalho produtivo (voltado à reprodução material) e reprodutivo (referido à produção simbólica, isto é, dos valores comunitários) não pode ser separado, posto que a Adesco e o RVM tornaram-se espaços de produção de consenso e suporte à liderança, cimentando a vida material e simbólica da Comunidade.

Desse modo, o apego e o sentimento de pertencimento à comunidade, relatados pelos pesquisados, estão diretamente relacionados a um conjunto de relações e de práticas sociais tradicionais, que conjugam trabalho, religião e família sob o princípio da reciprocidade. Mas, que não mais se restringem mais à produção agrícola ou às trocas que se mantém com a "terra", em função da agricultura.

\section{DIVISÃo SEXUAL DO TRABALHO, HIERARQUIA E PAPÉIS DE GÊNERO}

O entendimento do que é trabalho para os sitiantes só ganha clareza quando oposto ao lazer. Assim, o tempo de trabalho é oposto ao de tempo livre. $\mathrm{Na}$ área pesquisada, os sitiantes consideram trabalho essencialmente o trabalho no roçado/agricultura (domínio do masculino), o comércio/negócio, o "emprego" fora da propriedade rural, que pode estar ou não relacionado a atividades agrícolas, mas que normalmente é referido ao trabalho assalariado. E nesse sentido constatou-se que muitos sitiantes trabalham como servidores públicos, atuando como professores, agentes de saúde, 
vigias etc., além de muitos outros trabalharem como pedreiros, mototaxistas, e que os mais idosos recebem o beneficio da aposentadoria.

Por oposição, tempo livre refere-se ao tempo em que o indivíduo pode fazer o que lhe apraz, o que não significa que esse tempo não esteja sujeito a regulação da família e da comunidade. Por lazer, entende-se as atividades voltadas à diversão, distração e entretenimento, opondo-se às "obrigações" (atividades relacionadas à manutenção da casa, como limpeza e preparo das refeições; cuidar dos bichos ou manutenção de equipamentos de trabalho ferramentas, etc.) e ao "trabalho".

Não raro, o trabalho familiar (na agricultura, que recebe, direta ou indiretamente, a contribuição dos membros da família) é visto em oposição ao trabalho assalariado, ainda que, objetivamente, não haja uma contradição necessária entre ambos (WOORTMANN, 1990). Assim, o trabalho com os pequenos animais (galinhas, porcos etc.) e o trabalho doméstico - ambos tarefas realizadas pelas mulheres, portanto, domínio do feminino - não são percebidos como "trabalho" (WOORTMANN, 1986). Ou quando o são, são denominados de "trabalho leve", em oposição ao "trabalho pesado" realizado pelos homens, numa divisão relacionada muito mais com os papeis de gênero do que com o esforço desprendido para executar uma tarefa (PAULILO, 2004). Conforme Lunardi (2010), as categorias "leve" e "pesado" instituem uma valoração segundo a qual o que é pesado tem valor e o que é leve não tem valor ou é considerado "ajuda". $\mathrm{Na}$ concepção dessa autora, o turismo é considerado uma atividade mais leve que a agricultura, o que justificaria o predomínio da mão de obra feminina (LUNARDI, 2010, p. 249).

Com efeito, o trabalho feminino é considerado uma "ajuda", cujo valor está no objetivo final (reprodução e manutenção da família) e não nas ações feitas individualmente. Na maioria das vezes, criar pequenos animais ou prestar um serviço pelo qual se receba uma "remuneração" incerta e diferente de um salário é concebido como um meio de complementar a renda da família ou formar um "fundo emergencial", pelo qual se obtenha algum dinheiro para enfrentar uma necessidade imediata (da mãe ou dos filhos) ou futura (um casamento, uma doença etc.). Esse é o caso do artesanato, produzido pelas mulheres na comunidade, algumas vezes com "ajuda" dos 
filhos/filhas, incluindo a participação eventual de crianças, ainda que isso não seja a regra, pois a prioridade atualmente é que estas estudem.

\section{Ajudar: um verbo conjugado pelas mulheres}

De acordo com Woortmann (1990, p. 29), "ainda que se trate, objetivamente, de uma relação de compra e venda de força de trabalho", conforme a lógica camponesa, a "ajuda” é uma categoria que expressa a reciprocidade entre iguais. Mas, por outro lado, "construindo-se o assalariamento como ajuda, elude-se a precisão daquele que se assalaria" (grifo do autor) e a condição de patrão daquele que contrata" (WOORTMANN, 1990, p. 29).

Sabendo disso, o que significa e qual(is) sentido(s) a ajuda tem para os envolvidos na produção da oferta turística na Comunidade? Para achar as possiveis respostas, convém "ouvir" as sitiantes mulheres, posto que o verbo “ajudar" seja conjugado (historicamente) mais por elas e a palavra "ajuda" faça parte da linguagem cotidiana destas, numa clara indicação de que essa categoria continua alimentando as percepções sobre o trabalho feminino na Chã de Jardim. Veja-se o caso da sitiante E04:

\footnotetext{
JR: O que significa ajudá? A senhora sempre ajuda no Restaurante? $[\ldots]$ eu sempre fui uma pessoa que nunca parei em casa. Eu sempre fui de ta ajudando. [...] Eu sou uma pessoa que sempre quando o povo precisa eu tô ali, pra ajudar... Porque eu tenho aquele prazer de ajudá. Eu num sei por que, Josilene, eu tenho aquele prazer. Oie, quando, as vez, as menina me chama ali [no Restaurante], eu vou bem dizer que eu num posso? Porque muitas vezes eu to tão cansada, mas eu vou. Pronto, sábado eu tava lá, porque teve o casamento, né? Aí eu disse desse jeito: “- De manhã eu não venho não, mas de tarde eu venho ajudá na janta". Aí tava lá fritano as carne: frango, linguiça... [...] As vez, quando eu me levanto, eu vou pra lá [para o RVM, em frente do qual mora]. As vez tem serviço pra fazer, eu ajudo um pouquim. [...] Porque tem pamonha e tudo pra fazer, né? Que eu faço [regularmente, as pamonhas]. Lavo os prato, no domingo... Aí ela sempre me dá, uma vez por mês, ela me dá cinquenta [reais], sempre foi cinquenta. Ai eu compro o meu remédio de pressão, já é uma ajuda. (E4: 55 anos; servidora pública; 14/01/2016)
}

A sitiante E04 na época da pesquisa ainda estava na ativa (aposentouse em maio de 2016) e trabalhava a tarde como merendeira em uma escola 
municipal, a cerca de 500 metros de sua casa, recebendo mensalmente por seu trabalho um salário mínino da Prefeitura Municipal de Areia. Quando não estava trabalhando na escola, ela ia regularmente "ajudar" no Restaurante. A casa de E04 é o verdadeiro “ponto de apoio" daquilo que denominei "vila da Chã ${ }^{10 " ~(o n d e ~ f i q u e i ~ h o s p e d a d a), ~ o ~ q u e ~ s i g n i f i c a ~ d i z e r ~ q u e, ~}$ quando falta algo - um tempero, um utensílio de cozinha, muitas vezes, a vizinhança recorre a ela, indo até sua casa pedir emprestado. Sempre gentil e prestativa, "ela ajuda todo mundo" - me informaram logo quando eu cheguei a Vila. Quando ela diz "Eu sempre fui de tá ajudando", penso que se deveria interpretar "Eu sempre fui de tá trabalhando", tendo em vista que o trabalho incorporou-se à sua vida desde muito cedo. Aos onze anos de idade foi entregue pelos pais a uma família de proprietários de engenho em Areia, que se incumbiu de "terminar de criá-la" (nas palavras dela), e desde então passou a "ajudar" nas tarefas da "casa grande". Ainda na mocidade foi enviada pela "dona da casa grande" para Recife, com a missão de "ajudar", tomando conta dos filhos de sua filha que se tornara médica, casara e na época trabalhava e morava naquela cidade. Passou quatro anos de sua vida cuidando das crianças da filha de sua "benfeitora" e, após esse período, retornou à "casa grande", de onde saiu apenas depois casar-se, em suas palavras.

A partir da fala de E04 e da observação, pode-se afirmar que o sentido de ajudar se confunde com o de servir aos outros, permitindo pensar que para ela isso é uma forma de se sentir útil e, talvez, justificar a própria existência como mulher. A necessidade de justificar a existência pelo trabalho e, no caso das mulheres, pela "ajuda", por mais absurda que possa parecer, parece coerente como justificativa para a alegria e o "prazer de ajudar", de atender e

\footnotetext{
10 Situada no Sítio Chã do Jardim, as margens da Rodovia PB 079, ao lado do Parque Estadual Mata Pau Ferro, a vila da Chã é um pequeno povoamento constituído por 10 casas residenciais e um edificio que abriga o Centro de Ecoturismo Jonas Camelo de Souza. As casas e esse edificio foram construídos com recursos de um Projeto financiado pelo Ministério do Meio Ambiente e pelo Banco Mundial, gerido de forma conjunta pela Universidade Federal da Paraíba, Sudema e Prefeitura Municipal de Areia. As residências foram construídas para atender as familias dos posseiros que moravam na área da Reserva. Das 10 casas entregues em 1996, cinco serviam de residência primária, três de residência secundária e duas estavam desocupadas na época da pesquisa de campo. Porém, apenas três das dez casas eram habitadas pelos proprietários originais, isto é, ex-posseiros que mantinham sítios na Mata Pau Ferro antes da transformação desta em reserva ecológica. As demais são ocupadas por filhos/familiares dos contemplados com as casas ou foram vendidas a terceiros, geralmente, outros sitiantes. Vale ressaltar que nenhum dos atuais moradores possui título de propriedade da casa onde mora.
} 
servir os clientes, turistas e visitantes. Afinal, segundo o modo de vida camponês e no reduto da casa/quintal, o que faz uma dona de casa e uma mãe senão servir ao marido, aos filhos e, eventualmente, às vizinhas? Todavia, essa alegria/satisfação em "servir aos outros", é preciso destacar, não está limitada às mulheres, embora esteja mais comumente associada às atitudes e explícita nas falas dessas. Homens também “ajudam" suas mulheres, quando realizam alguma atividade doméstica, dissimulando com essa noção a obrigação de dividir as tarefas igualmente.

A interação com os sitiantes, não apenas na Chã de Jardim, e a observação do cotidiano na comunidade, fazem-me pensar que a atitude e a alegria de servir ao outro esteja incorporado ao ethos camponês. Por outro lado, ajudar/servir/trabalhar torna-se uma forma de realização pessoal, que dá sentido a própria existência, especialmente das trabalhadoras mulheres majoritárias no Restaurante. Veja-se a fala de uma delas:

\begin{abstract}
JR: Você se sente recompensada de alguma maneira, por esse teu esforço a mais [horas de trabalho a mais]?

E27: Na alegria, né, me sinto, me sinto. É tanto que... Ontem mesmo aconteceu um fato engraçado. Você quer alegria maior do que ver aquela felicidade daquela mãe?! Com aquele aniversário [no dia anterior havia ocorrido uma festa de aniversário de uma criança no restaurante]. E você lá dento, trabalhano, trabalhano... cheguei em casa ia dar oito horas [da noite] e foi porque ainda ficou serviço pra fazer, mesa pra arrumar, troço pra guardar. Então, essas são as recompensas, né, ver aquela mãe tão feliz, com o trabalho da gente, com os meninos servidos! [...] E outras confraternizações que eu já cheguei em casa até de uma hora da manhã, tendo que escutar o forró comendo até uma hora da manhã... [da gargalhada] Mas, chego cansada, mas chego contente! Nunca cheguei triste, nunca cheguei. Nunca fizemos um serviço, um evento desse pra pessoa chegar e dizer assim "Num gostei!" (E27: 33 anos; Gerente do RVM; 29/02/2016).
\end{abstract}

O depoimento de gerente (extra-oficial) do RVM destaca a satisfação em trabalhar no Restaurante e em "atender/acolher bem", em "encantar o cliente" e em fazê-lo "sair satisfeito'. Seria a alegria declarada por E27 fruto da realização pessoal por realizar um trabalho que the confere um lugar de destaque no mundo ou por que 'servir ao outro', pessoalmente, permite que este expresse seu reconhecimento/gratidão imediatamente? Talvez as duas coisas, porque o trabalho no turismo propicia interação e oportunidades de trocas simbólicas (hospitalidade, amabilidade, comensalidades etc.) com os 
viajantes e turistas, através das quais as trocas ultrapassam, geralmente, a impessoalidade que predomina nas relações meramente mercantis. Isso porque o turismo é um serviço intangivel, que implica presença, interação e consumo imediato, ou seja, uma experiência sensorial em que as pessoas (turistas, excursionistas, viajantes) estão predispostas ao relaxamento e abertos a trocas mais subjetivas, posto que estejam vivenciando um momento de lazer e entretenimento (SILVA, 2009).

Dessa forma, o valor de troca mercantil dado pela compra e venda do serviço de alimentação, por exemplo, parece reconvertido em valor de uso, que é traduzido na hospitalidade, num acolhimento caloroso e no "bem servir" os viajantes/turistas/clientes - que representam o "outro" para os sitiantes, dentro dessa relação. Todavia, não se pode esquecer que o acolhimento e o servir ao outro corresponde à essência do trabalho na linha de frente com os turistas. Talvez por isso os sitiantes e mais explicitamente as sitiantes tenham tanto prazer em realizar tal trabalho e sejam tão exitosas na "arte da hospitalidade" e do acolhimento caloroso, que caracteriza e diferenciam o Restaurante Vó Maria de outros estabelecimentos, segundo todos os entrevistados que trabalham no local.

\section{Trabalho e busca de autonomia pelas mulheres}

Embora o trabalho das mulheres no turismo esteja associado a servir ao outro, no Brejo paraibano, o trabalho também representa a busca de autonomia financeira e de liberdade individual, traduzindo-se numa maior "disposição para empreender", isto é, para trabalhar e criar o próprio negócio. Apesar de não possuir dados estatísticos que comprovem essa conclusão, há pistas suficientes que levam a essa hipótese, pois, apenas em Areia, de 10 empreendimentos voltados ao turismo, que surgiram nos últimos 10 anos, seis são dirigidos e liderados por mulheres. Isso poderia induzir a pensar que as mulheres envolvidas na produção da oferta turística estão rompendo, simultaneamente, com o papel feminino tradicional - de dona de casa e mãe - e com a posição de subordinadas, rebelando-se definitivamente contra a violência simbólica inerente às relações de gênero na família (BOURDIEU, 1999; GAVIRIA e PEZZI, 2007). Porém, todos os seis 
empreendimentos estão vinculados aos segmentos de alimentação, de hospedagem ou de confecção de artesanato e, em apenas um caso, de cultivo de flores, logo, à esfera doméstica, domínio do feminino.

O protagonismo das mulheres na produção da oferta turística, especialmente, nos segmentos de hospedagem e de alimentação, não é uma novidade, conforme apontam os estudos sobre o tema (TALAVERA, 2000). Gonzales (2005), por exemplo, constatou que as mulheres correspondiam a $68 \%$ do pessoal ocupado em atividades de turismo rural na região Castilla y León, na Espanha. Raquel Lunardi, em sua pesquisa de mestrado, realizada na região de Campos de cima da Serra, no estado do Rio Grande do Sul, em 2007, também atestou o predomínio das mulheres à frente de pousadas e restaurante rurais. De acordo com Lunardi (2010, p. 244):

A significativa participação da mulher nessa atividade pode ser justificada pelo caráter doméstico (domiciliar) que as tarefas exercidas por elas no turismo apresentam, permitindo que a atividade se configure, em muitos casos, como uma extensão das tarefas domésticas.

Reforçando tal argumento, ao visitar uma pousada/rancho rural, oficialmente registrado em nome de uma mulher, fui recebida e entrevistei o marido desta, que explicou as atividades realizadas pelos dois da seguinte forma:

\begin{abstract}
E aqui na parte do Rancho é o seguinte: minha esposa, ela toma conta da alimentação, na cozinha. Ali ela trabalha com cerca de 8 pessoas, na cozinha, ela quem gerencia e quem dá as diretrizes e ela vai pra... Não tem esse negoço de tá mandando não, ela vai pra panela mesmo, pra cozinha. Ela mete a mão na massa mesmo. [...] Na parte de alimentação é mais com ela. E a parte fora, de estrutura, de trilha, de caminhada, os contatos... tudo é comigo. (E21: 43 anos; comerciante/empreendedor do turismo; 26/02/2016).
\end{abstract}

A fala de E21 confirma outras observações pelas quais constatei que as mulheres se ocupam com frequência da cozinha, da alimentação, reproduzindo o papel tradicional de gênero. Vale destacar que, quando tentei o contato para a entrevista, os informantes me encaminharam diretamente ao "dono" do estabelecimento, que prontamente se dispôs a me conduzir para conhecer o local em data e horário agendados. Assim, sua esposa sequer esteve no local no momento da entrevista. Isso porque, no caso desse 
empreendimento, marido e mulher não moram no local, situado há alguns quilômetros da sede do município de Areia.

Desse modo, a ocupação pelas mulheres dos segmentos supracitados no Brejo paraibano sugere que não se pode falar em rupturas dos papeis de gênero nem tão pouco da hierarquia presentes nas relações familiares. Como bem salientou Sarti (1994, p. 84): “Isto significa que, mesmo nos casos em que a mu1her assume o papel de provedora, a identificação do homem com a autoridade moral, a que confere respeitabilidade à família, não necessariamente se altera". Por outro lado, não se deve negligenciar o fato de que o turismo na área pesquisada venha se constituindo o dominio das mulheres, posto que, incluindo a líder, as mulheres constituem $63,3 \%$ da mão obra envolvida diretamente no turismo na Chã de Jardim, por exemplo.

\section{TRABALHO PARA AS ARTESÃS: TECENDO SABERES, IDENTIDADES E REDES DE SOCIABILIDADE}

$\mathrm{O}$ artesanato tem um papel fundamental para o desenvolvimento da oferta turística na Chã do Jardim e no fortalecimento dos elos comunitários e da liderança. Dentro da oferta turística a função do artesanato é conferir autenticidade e oferecer uma representação identitária ou do estilo de vida dos sitiantes, ao passo que os visitantes e turistas buscam nas áreas rurais algo diferente do seu próprio habitat (TALAVERA, 2000), segundo a noção romântica de que os agricultores são guardiões da tradição e da natureza, vivendo mais próximo dessa que os moradores da urbe.

Para entender a importância do trabalho com o artesanato na reconfiguração das identidades das sitiantes na área estudada, recorro à recomposição (sumária) da trajetória do grupo de mulheres responsável pelo "Projeto Arte na Mão".

Entre os anos de 2006 e 2007 duas turmas do Programa Brasil Alfabetizado foram organizadas na comunidade, tendo a líder comunitária que nasceu e cresceu na comunidade e que se formou em história por uma universidade pública - como professora de ambas. A segunda turma, vinculada ao "Programa Saberes da Terra11", foi formada apenas por

\footnotetext{
11 Implementado pelo Governo Federal em 2005, o projeto Saberes da Terra faz parte do programa de Educação de Jovens e Adultos (EJA), que oferece qualificação profissional e escolarização aos
} 
mulheres e as aulas foram ministradas numa antiga casa de farinha, na comunidade rural "Gruta do Lino". O local foi escolhido pela própria professora, que pretendia facilitar o acesso das alunas, arregimentadas uma a uma por ela mesma, sob o argumento de que até sua mãe iria voltar à sala de aula. Denominada "Nunca é tarde para recomeçar", a turma era formada apenas por mulheres adultas e casadas, algumas ainda com filhos pequenos.

A sensibilidade da professora diante da situação das mulheres, aliada às diretrizes do curso - que previa o estímulo ao desenvolvimento de atividades de educação ambiental e produtivas, por meio da organização de hortas e pomares -, fez com que surgisse a proposta de produção de peças de artesanato com matéria prima local. A ideia da professora e líder comunitária era que as peças fossem exibidas e vendidas aos visitantes da Mata Pau Ferro, gerando renda para as mulheres, que, em geral, dependiam integralmente dos maridos. Segundo a lider, ela teria atendido ao apelo das próprias alunas que diziam: “- A gente podia fazer alguma coisa pra gente ganhar algum dinheirinho pra ajudá em casa”. A proposta de fazer artesanato não era de todo novidade para as mulheres. O desafio parece ter sido criar algo original e com matériaprima não usual, disponivel na localidade: a palha da bananeira, abundante graças aos muitos plantios nas fazendas e em parte das áreas de antigos engenhos em fogo morto, onde elas ainda hoje vão buscar ${ }^{12}$ mensalmente essa matéria-prima. Conforme os relatos, após a tentativa frustrada de usar material reciclável (jornal) para criar as peças de artesanato, seguindo-se as dicas de pessoas externas, as artesãs optaram por usar a palha da bananeira como forma de criar e remarcar a identidade local.

\footnotetext{
agricultores familiares que não concluíram o ensino fundamental. O programa articula atividades de tempo-escola e tempo-comunidade, com educadores das áreas de ensino fundamental e das ciências agrárias, durante um a dois anos. As aulas são ofertadas na própria comunidade rural, incluindo atividades práticas de produção e manejo de agricultura sustentável. Luciana Balbino foi selecionada por edital/indicação e foi a educadora responsável por ministrar o curso por dois anos, na área de ensino fundamental, na sua própria comunidade. (BRASIL/MEC, 2017).

12 As artesãs juntam-se uma vez ao mês e fretam um carro pelo valor de R\$ 80,00 para buscar palhas em algumas fazendas previamente definidas e para as quais obtiveram autorização do proprietário para retirar as palhas dos bananais. A obtenção de autorização demandou, no início, a mediação de um professor da UFPB- Campus Areia, posto que houve um caso de ameaça de violência física contra às mulheres por causa da entrada delas nos plantios de bananais, em uma determinada fazenda. Esse caso é relato pelas artesãs como momento de grande tensão, que fez algumas desistirem da atividade.
} 
A produção de um artesanato com função utilitária fazia parte dos saberes tradicionais de alguns sitiantes idosos da comunidade e que estava (e está) em vias de desaparição, posto que não haja demanda e que as novas gerações não tenham interesse nesse saber. Esses idosos, no passado, sobreviveram justamente dos rendimentos da agricultura e do artesanato, produzido pelo conjunto da família, no seio da qual o saber era transmitido, conforme relata as entrevistadas E11 e E03:

E11: [...] Nesse tempo que eu me casei nói já fazia balai, num era mas nem alugado [o trabalho], era do balai. Vivia do balai. [...] Tinha o homê que vinha vê [buscar] toda semana. Trazia um caminhão e era caçuá, balai, cesta e até os cambote [cambito] a gente fazia aqui. Se ajuntava eu, meu marido, meu pai, minha mãe, tudinho fazia, sabe? Aî ele levava. Aî depois que ele foi simbora, aî nói fiquemo carregano pa Esperança [principal feira livre das cidades do Brejo, após a decadência da feira de Areia]. Meu pai era mai novo, aí ele butava na besta [animal de carga] e nói ia pa Esperança. Aí depoi nói fiquemo vendeno aqui em Remijo [Remígio, cidade vizinha a Areia]. [...] Aí depoi foi tempo que eu me aposentei, aí ninguém fez mais $[\ldots]$

JR: E as peças que senhora fez para o Restaurante?

E11: Ah, eu fiz, eu faço cadeira, aquelas rede que tem lá tudo é eu, aquelas cadêra, aqueles balanço, tudo é eu. Tudo, aquilo tudo de cipó.

JR: E a senhora trabalha só ou algum dos seus filhos aprendeu?

E11: - É eles mermo, eu e eles. [Porque] Eu, agora mermo, a pessoa vai ficando de mais idade num tem mais saúde pa tá dento dos mato não, caçano cipó. Aí quando Luciana encomenda essas coisa assim rede, caçuá, essas coisa assim - eles se ajunta e vai tirá o cipó e eu faço aqui mais eles. (E11: 65 anos; agricultora aposentada e artesã; 29/01/2017).

E03: [... Era essas peças que minha mãe fazia: era essa panelinha, que era de cozinhar; era a chaleirinha de fazer café, era /bulim/ e era o /pratim/... Era as peça que minha mãe, a minha vó fazia... Era que chamava tigelinha, era marmitazinha, era a chalerinha e o /bulezim/. E o fogareiro a carvão. Então a gente se criô vendo esse /trabalhim/ de mãe, que foi esse daqui. [...] E esse /trabai/ aqui era mais pro verão, num sabe? Tempo de inverno a gente tava /trabaino/ na roça, era /prantano/ feijão, era milho, era fava... [...] Mas hoje, a juventude de hoje num /quere/ fazer mais esse / siviço/ não.

$J R: E$ as bonequinhas, as carinhas de boneca apareceram quando?

E03: Essas bunequinha... [pega uma boneca quase pronta nas mãos e começa a dar acabamento na peça de barro] essas /bunequinha/ já foi depoi que a gente já idosa /mermo/... A gente não sabia fazer, ai o povo vem e traz as mostra, os modelo pra gente fazer até aqui... O povo já traz as formosurazinha e aí a gente já vai... [...] Mas, a gente pra aprender aquela a gente foi até Caruaru. A gente num sabia o que era fazer, foi muito /trabai/. Só quem faz essas bunequinha, aqui na Chã da Pia, só é eu. [...] É muita coisa pra fazer. É / mio/ fazer três panelas do que fazer uma bonequinha dessas! (E03: 58 anos; Agricultora aposentada e artesã, Comunidade Chã da Pia, 13/01/2016). 
A chegada do turismo, no início dos anos 2000, e dos turistas à Areia, à Chã de Jardim e à Chã da Pia $^{13}$ reacendeu o interesse pelo artesanato como atividade econômica, embora muitos sitiantes houvessem abandonado a prática há alguns anos. O abandono da produção ocorreu possivelmente em razão do desuso e da substituição dos utensílios por outros industrializados, que resultou na desvalorização de objetos como balaios, caçoas - muito usados pelos sitiantes, no passado, para o transporte de cargas na produção agrícola, feito em lombo de animal -, assim como das loiças de barro e urupemas - usadas tradicionalmente pelas famílias mais pobres em suas cozinhas. Todos esses itens e vários outros, como conchas em madeira (quenga de coco), abanadores de fogo, bonecas de pano, são usados atualmente como objetos de decoração no RVM e comercializados na "loja de artesanato" (ao lado do Restaurante) como signos ou ícones de um modo de vida tradicional dos camponeses e que estaria em vias de desaparição.

Figura 03: Elementos de decoração do restaurante
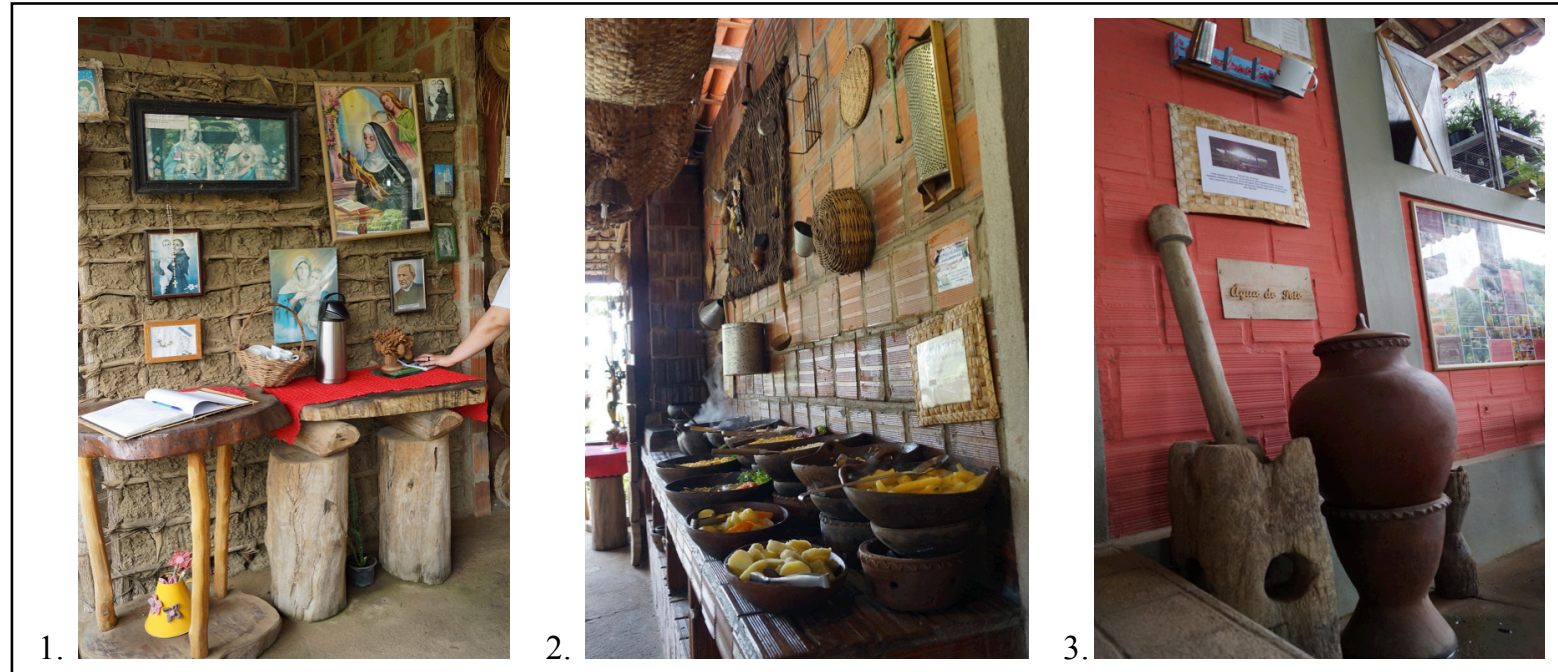

Fonte: Arquivo pessoal, 2016.

A atividade econômica do turismo leva não apenas à revalorização, mas a um "renascimento" e à ressignificação do artesanato na comunidade rural e

\footnotetext{
${ }^{13}$ A comunidade rural Chã da Pia, localizada na divisa entre os municípios de Areia e de Remígio/PB, é responsável por uma técnica tradicional de produção de loiças de barro/argila (cerâmica utilitária), transmitida de geração a geração. A associação de artesãs da localidade é formada basicamente por membros uma grande família-tronco, que mora na localidade há muitos anos. A entrevistada E03 faz parte dessa comunidade.
} 
da própria condição das mulheres engajadas na atividade. Ressignificação porque de objeto de uso tradicional na cozinha ou no trabalho agrícola eles passam a objeto de decoração, representando a cultura popular, que também passou por um processo de reconhecimento e valorização, transformando-se em um produto e um recurso da indústria do turismo (YÚDICE, 2002; TALAVERA, 2003). E além de se reinventar as funções, cria-se novos objetos: cadeiras e redes de cipó, bonecas em argila (em "loiça de barro"), jogos americanos e pastas (porta papel) em palha de bananeira, por exemplo. Verifica-se, dessa maneira, uma ressignificação do artesanato e de seus produtores, que passam a ser considerados como representantes de uma identidade e de uma cultura que precisam ser preservadas e conservadas, conforme as políticas e as estratégias empresariais que preconizam a exploração turística dos recursos patrimoniais (TALAVERA, 2000; 2003), dentro do denominam economia criativa ou indústria criativa.

Figura 04: Peças produzidas pelas artesãs da Chã de Jardim.

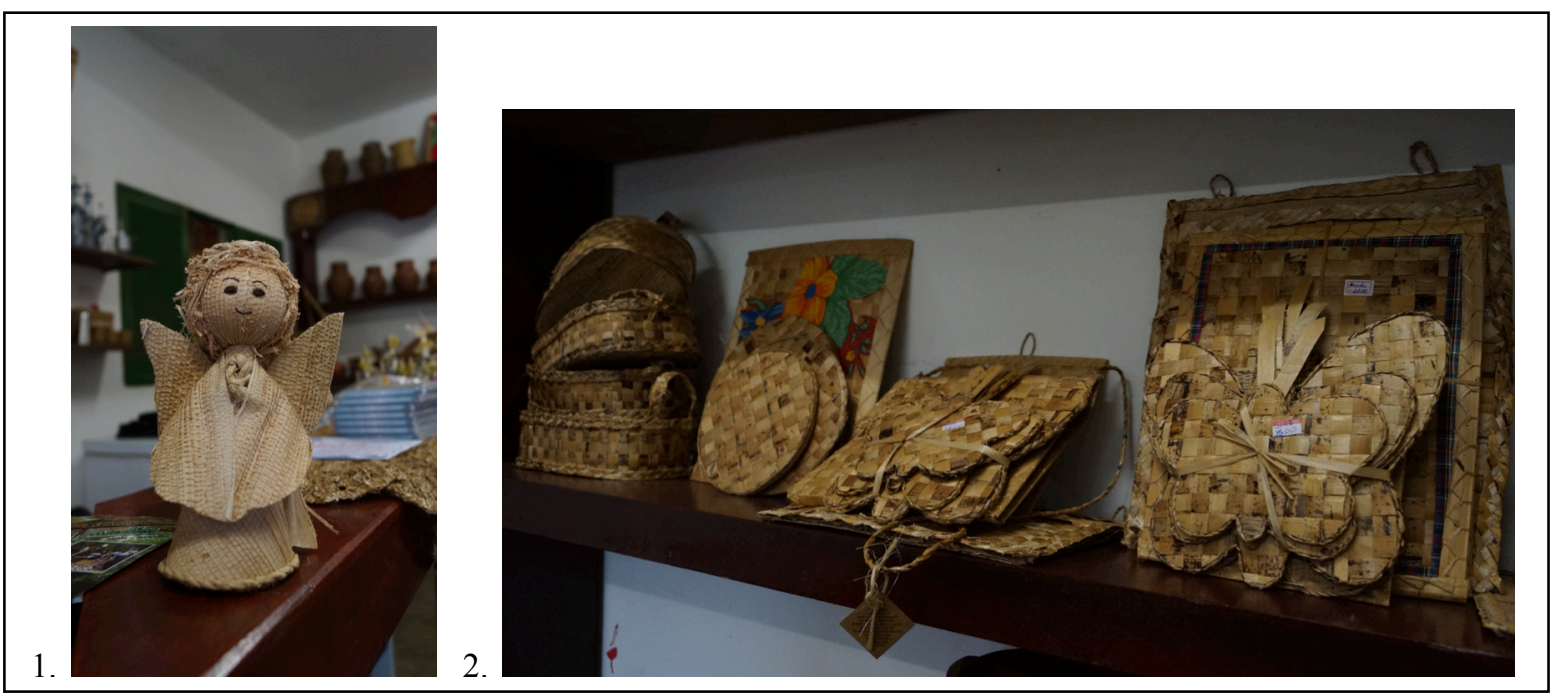

Fonte: Arquivo pessoal, 2016.

Isso se torna muito significativo para as mulheres, que passam a perceberem-se como detentoras de um conhecimento particular, que as retira da "reclusão" da casa-quintal e da situação de inferioridade resultante da posição de "dona de casa" (LUNARDI, 2010), cuja função não requer uma qualificação específica e justamente por isso pode ser feito, supostamente, 
"por qualquer pessoa". Algo que sobressai nas falas de todas as artesãs, quando perguntadas sobre o quê o artesanato significa na vida delas.

E05: Significa muita coisa, porque pelo menos eu sei que eu já sei de algo, né, que é de mim mermo. E se eu precisar alguma coisa, eu vendo uma pecinha, quando vendo aquilo ali já me ajuda bastante. E assim eu fico feliz. Ai eu me orgulho do que eu faço. [...] A gente sente prazer em saber produzir aquilo ali. [...] Assim, porque se me perguntare "- Você trabalha em quê?" Aî, eu digo: Olhe, de tudo eu sou um pouco. Eu sou agricultora e sou uma artesã! E sou mãe e sou dona de casa. (E05: 47 anos; artesã e agricultora; $15 / 01 / 2016)$.

E06: [silêncio, pensa antes de responder] Assim, por menos que seja... Porque eu num vou dizer... A ninguém eu vou dizer que a gente ganha salário, porque eu também num posso mentir, né. Mas, assim, eu acho bom. Eu gosto. $\mathbf{E}$ quando a gente se juntava tudo, ainda era até melhor, porque tava ali unido. E conversava e ria e cantava, e talvez até chorava. Quando se emocionava com alguma coisa, chorava. [...] As vez eu fico pensano... Porque no início eu num sabia fazer. Eu olhava assim, eu achava as peças tão mal feita. As vezes leva até mal feita pra lá, eu num vou negar não. [...] Ai eu fico pensano assim: "- Como foi que Deus deu uma chance pra gente?" Deus deu uma chance pra gente! [...] Ai eu digo assim: "- Oie, um dia se eu deixar, mas vocês num deixê, [pois] essa é uma herança que vocês vão ficar pra vocês". (E06: 54 anos; agricultora e artesã; $15 / 01 / 2016)$.

As artesãs revelam grande orgulho de si mesmas, por terem desenvolvido um conhecimento que fez delas “artesãs”, elevando seu status na comunidade. Porém, elas em nenhum momento abandonam a identidade de dona de casa ou de agricultora, como indica a fala da artesã E05. Certamente, porque o papel de "dona de casa" está intrinsecamente ligado à identidade de gênero da mulher, casada e mãe.

No cotidiano da comunidade, parece que, automaticamente, quando uma mulher se casa, "nasce uma dona de casa e uma mãe", desempenhando um papel central para a reprodução da família, embora isso não seja valorizado (WOORTMANN, 1991). A identidade de agricultora, vale salientar, foi incorporada recentemente, em função das conquistas de direitos pela mulher trabalhadora rural: aposentadoria, acesso às politicas públicas de apoio à agricultura familiar etc. Ademais, o orgulho das artesãs também se deve ao fato delas terem vencidos as criticas de outros sitiantes da própria comunidade e de seus familiares, que diziam que elas não iriam ganhar dinheiro com aquilo e que iriam "ficar doidas". 
Trabalho e produção associada ao turismo | Josilene Ribeiro de Oliveira

Ainda que a remuneração recebida por elas com as vendas das peças ${ }^{14}$ seja baixa, algumas entendem que o saber, isto é, o conhecimento de como produzir o artesanato, é um patrimônio que precisa ser transmitido como uma herança para as outras gerações, como sugere a fala da artesã E06. Outro aspecto que chama atenção é que a retomada dos estudos e os momentos de produção conjunta do artesanato no Centro de Ecoturismo, na Chã do Jardim, são lembrados por essas mulheres com saudosismo. Para muitas delas aqueles eram momentos de sociabilidade, de encontros e reencontros com as vizinhas e/ou parentes ${ }^{15}$.

É possivel afirmar que muito mais que rendimentos financeiros, a experiência do retorno à sala de aula e do trabalho com o artesanato abriram para as mulheres o acesso a uma rede de sociabilidade que lhes trouxe reconhecimento e valorização, não apenas diante de seu grupo familiar e de sua comunidade. "Artesã" revela-se uma identidade profissional e social valorizada e reconhecida a partir do exterior, embora assentada em um conhecimento que algumas delas já possuiam, mas que não gozava de reconhecimento local. Quando algumas das artesãs foram convidadas a conceder entrevistas a jornalistas e a ministrar oficinas para os turistas, o grupo conquistou grande visibilidade e ocorreu uma ruptura na trajetória delas, que passaram a assumir também a identidade de artesãs.

O resultado mais visivel desse reconhecimento parece ser o aumento da autoestima e o fortalecimento dos laços afetivos entre "as meninas do artesanato" (como elas referem-se ao grupo), que encontraram na produção do artesanato momentos de sociabilidade que lhes garantia um tempo que lhes fosse próprio, um espaço de conversas e de troca de experiências. Em outras palavras autonomia sobre o processo de trabalho no artesanato e o tempo que

\footnotetext{
14 As peças de artesanato na palha de bananeira mais vendidas são, em ordem de importância: as pastas (porta papel e documentos), jogos americanos, descanso de panelas, portas-treco, flores sobre canetas, bolsas e mandalas (esses dois últimos são feitas apenas por uma das artesãs). Verifica-se que, em sua maioria, trata-se de peças utilitárias, sugerindo que apesar da inovação no tipo de material usado e das peças produzidas, o artesanato continua tendo função utilitária. A inspiração para produção das peças continua sendo majoritariamente intuitiva, posto que a participação em curso não resultou, com exceção das bolsas (femininas), em novidades e não alterou o processo de produção.

15 Muitas artesãs têm algum grau de parentesco entre si: há pelo menos um caso de uma família em que avó, filha e neta trabalham com o artesanato e muitas artesãs são primas e/ou comadres umas das outras.
} 
passavam juntas, durante o qual elas "[...] conversava e ria e cantava, e talvez até chorava ${ }^{16 "}$.

O grupo ${ }^{17}$ de artesãs, que passou a ser denominado Projeto Arte na Mão, em seu início chegou a reunir cerca de trinta mulheres. Mas, atualmente, é constituído por apenas cinco mulheres do grupo original - que iniciaram juntas a atividade no intervalo das aulas do Programa Saberes da Terra - e mais três jovens, filhas de três delas. "O grupo foi afracano, mas noi nun vai deixa se acabá e LB [lider] luta pra gente permanecê", disse-me uma delas. De fato, a líder parece ter consciência do quão o grupo é, simbolicamente, importante para a Comunidade.

Do ponto de vista da liderança da Comunidade Chã de Jardim, o trabalho a frente do Projeto rendeu uma grande projeção para o turismo local, como se depreende de seu depoimento escrito em 2007, o qual transcrevo abaixo.

Quanto ao artesanato, acredito que ele chegou a um patamar que nem mesmo os mais otimistas imaginavam. Recebemos uma encomenda de 600 pastas para um evento da Faculdade de Comunicação Social da UEPB, em Campina Grande, além de mais 250 para um congresso e fomos sondadas por estudantes da Faculdade de Administração para confeccionar 1.500 pastas para um encontro que será realizado em novembro. Também fomos convidadas a participar do $6^{\circ}$ Salão de Artesanato Paraibano. Entretanto, o mais importante foi o destaque que tivemos na TV Paraiba numa reportagem exibida no programa Paraiba Comunidade, no Bom dia Paraíba e no JPB, que trouxe turistas japoneses e holandeses para nos visitar (Editorial escrito e assinado pela professora Luciana Balbino para o Jornal Saberes da Terra - Escola Nunca é Tarde pra Recomeçar. Ano I, no ${ }^{\circ}$ 2; Julho de 2007).

Com apoio do Sebrae/PB obteve-se projeção na mídia, que se interessou pelo tema da criação de uma alternativa para geração de renda

\footnotetext{
16 Apesar de não ter presenciado nenhuma desses encontros produtivos, é possível pensar que tanto o canto quanto o choro configurava uma experiência de partilha e expressão livre de toda infelicidade e toda angústia das mulheres, aproximando-se da situação das mulheres guaiquis observada por Pierre Clastres e citadas no artigo "O arco e o cesto", no qual o antropólogo discute a divisão sexual do trabalho e a vida cotidiana dos Guayaki (CLASTRES, 1978).

17 Das oito mulheres que constituem atualmente o grupo de mulheres artesãs seis foram entrevistadas, além de outras duas que abandonaram o Grupo por razões de saúde ou pessoais. O perfil das artesãs entrevistadas compreende mulheres com idades entre 24 e 65 anos, em sua maioria casadas, estando apenas duas delas ainda solteiras, residentes nos sitios/povoados de Gruta do Lino, Tabuleiro de Muquém, Muquém, Sítio Jardim. Independente das localidades onde moram as mulheres, o artesanato e o grupo é conhecido como pertencente à Comunidade Chã de Jardim. O grupo de artesãs "Projeto Arte na Mão" é totalmente informal. Assim, quando ocorre uma encomenda e venda um volume de peças grande para um comprador institucional (universidade etc.) e é preciso emitir nota fiscal, por exemplo, é o Restaurante Vó Maria que fornece.
} 
para as mulheres rurais, por meio do artesanato. A divulgação, articulada por meio de ações do Sebrae junto às agências de viagem, trouxe visitantes para conhecer a experiência da comunidade, coincidindo com o momento em que a Adesco estava começando suas atividades com a produção e a comercialização da polpa de frutas. Sem dúvidas a visibilidade midiática foi essencial ao sucesso obtido com o artesanato, posto que gerou reconhecimento para as artesãs. Entretanto, aos olhos dos demais sitiantes, o "trabalho com o artesanato" ainda representa apenas uma ajuda financeira para as mulheres e suas famílias.

Conforme constatei, a renda obtida com o artesanato é usada de diferentes formas pelas artesãs. Porém, observa-se certa regularidade/padrão no uso do dinheiro pelas mulheres: as casadas investem na casa, dão aos filhos ou compram aquilo de que eles necessitam e, apenas quando essas necessidades são satisfeitas, elas pensam nelas próprias, com algumas poucas exceções a essa regra; as solteiras frequentemente compram objetos de uso pessoal, geralmente roupas, calçados etc. Todas, mulheres casadas e solteiras, já compraram algum objeto religioso (terço, camiseta, livro de cantos etc.) para uso pessoal ou familiar com o dinheiro do artesanato. Desse modo, destaca-se que o trabalho e seu resultado financeiro são concebidos, entre as mulheres casadas, como um projeto familiar voltado para o bem estar da família (SARTI, 1994). E, inclusive, para atender grandes encomendas, "famílias inteiras" (excetuando-se o marido) podem engajar-se na produção do artesanato, conforme me relataram algumas artesãs. No entanto, entre as mulheres mais jovens, o trabalho e o uso dos rendimentos assumem um caráter mais individual, não sendo possivel afirma se isso é o resultado de uma postura mais individualista ou, simplesmente, da condição de jovem solteira, logo, sem responsabilidade direta pela manutenção da família.

Vale destacar que não há nenhum vínculo formal, nem as artesãs são assalariadas da Loja (bodega) do Vó Maria, posto que elas recebem apenas pelo que for vendido. As artesãs são remuneradas pelas peças vendidas, deduzindo-se de $10 \%$ a $15 \%$ do valor final (estabelecido por elas para cada peça), destinado à manutenção da loja de artesanato. 
Como narra a sitiante e artesã E12, o artesanato é para muitas delas uma espécie de terapia, de distração e não um trabalho.

\begin{abstract}
Aí comecei fazeno essas boneca e levando lá, na loja. Era nesse tempo, quando começô, era no ôtra [loja] do lado, na sede. E daí até hoje eu ainda to fazendo. E graças a Deus, acho muito bom fazer porque é até uma terapia pra gente, que já ta assim de idade, que num pode mais sair pra trabalhar no roçado, nem fazer ôtas coisa. Vamo, fico aqui o dia todo, faço minhas coisa em casa e... o tempinho que eu tenho eu to na máquina [de costura], faço uma boneca... você viu né, os chaveiro, as bonequinha na loja. Até hoje eu levei pra lá uns colarzinho, de fuxico também. [...] Olhe, eu vou fazendo só com o tempinho que eu tenho, que eu arranjo, né. Eu num deixo de fazer minhas coisas, nem de fazer minhas viagem/, meus passeios, nem de fazer as ôta coisa, pra só ta fazendo [artesanato], né. (E12a: 61 anos; agricultora aposentada, artesã; 29/01/2016).
\end{abstract}

O depoimento da artesã E12 e de outras sitiantes-artesãs indica que elas procuram preservar a autonomia sobre o próprio tempo. Nesse sentido, ainda que a justificativa oficial tenha sido a diminuição do número de encomendas, o que de fato parece ter motivado a interrupção da produção conjunta, feita na sede da Adesco/Centro de Ecoturismo, na Chã, e a decisão das mulheres de produzir em suas próprias casas, individualmente, foi o desejo de manter certa autonomia sobre o ritmo de trabalho. Com efeito, a ausência das mulheres do lar também causava desconforto na relação com os maridos, afetando certamente tal decisão.

Seja em razão de colocar a "família" em primeiro lugar ou por querer assegurar a gestão e o ritmo do próprio trabalho, pode-se aventar que, do mesmo modo que os homens, ter autonomia e controle sobre o tempo e o volume da produção de artesanato configura um ponto de honra para as sitiantes-artesãs. Autonomia e honra que fazem com que elas não se sintam “empregadas de ninguém”. Em conclusão, isso parece ser essencial para preservar para elas mesmas o caráter de escolha e de realização pessoal com o artesanato. Dessa maneira, as artesãs parecem estar em uma tensão continua entre: responder ao "compromisso moral" de manter o grupo permanentemente ativo; atender a demanda da liderança por produtividade, para satisfazer as demandas dos turistas e visitantes; e preservar a condição de autônomas e livres da subordinação de "um patrão".

\title{
CONSIDERAÇÕES FINAIS
}


$\mathrm{Na}$ Chã de Jardim, o trabalho agrícola e não agrícola passou a ser vinculado à cadeia produtiva da atividade turística. Todavia, o circuito de circulação de dádivas que se desenvolveu junto com a produção da oferta turística na comunidade, o qual é movido pela força invisível da reciprocidade, permite a ressignificação de valores tradicionais.

O trabalho e a remuneração são objetos mediadores das trocas simbólicas e materiais que sedimentam a coesão e as alianças na Comunidade. No âmbito do RVM, “deposita-se confiança em" oferecendo-se oportunidade de trabalho e, em troca, recebe-se "ajuda" na forma de força de trabalho. Em retribuição ao trabalho/engajamento, "doa-se" uma remuneração (na forma de salário, “ajuda” ou "agrado"), que simboliza o reconhecimento de uma divida moral, entre indivíduos que se vêem moralmente como iguais, embora reconheçam e considerem legítima a hierarquização das relações de trabalho, possivelmente porque esta reproduz a forma como se estrutura a família camponesa tradicional, a qual todos tomam sempre como referência. Assim, a troca de trabalho por remuneração materializa a troca de confiança, realizada no plano simbólico. E a obediência/submissão ao líder-patrão corresponderia à deferência devida ao pai-patrão tradicional, ao qual a mulher e os filhos eram/estão subordinados. Efetivamente, é através de trocas objetivas e subjetivas que se cria valor econômico e circulam-se valores morais na Chã de Jardim. Vale ressaltar que tanto o Restaurante como a Loja/Budega do Vó são espaços de trocas múltiplas, pelo qual circula não apenas dinheiro/rendimentos, mas sim "valores" e representações de mundo, envolvendo consumidores, produtores/fornecedores, turistas, visitantes e sitiantes, citadinos e rurais. Não por acaso, os planos material e simbólico são indissociáveis na vida comunitária, justificando a articulação contínua entre atividades religiosas, produtivas e econômicas, tal qual Mauss (2003) observou nas sociedades estudadas pelos antropólogos ${ }^{18}$ de sua época.

\footnotetext{
18 Salvo uma pequena experiência de poucos dias no Marrocos e de algumas breves viagens a países estrangeiros, Marcel Mauss nunca fez trabalho de campo. O material analisado por ele e que serviu de base ao Ensaio sobre a dádiva provém dos estudos etnográficos de Bronislaw Malinowski acerca do intercâmbio do kula entre os trobriandeses, em 1922; e das pesquisas de Franz Boas sobre a instituição do potlatch entre os índios da costa do Pacífico no Noroeste da América do Norte, em 1899; além de
} 
Ademais, observou-se que o valor do trabalho expressa um julgamento, jamais uma propriedade intrínseca a uma atividade em si, conforme sugere Appadurai (2008) inspirado em Simmel (1978). Isso explica porque na divisão sexual do trabalho o masculino é mais valorizado em prejuízo do trabalho feminino, que é considerado ainda como complementar, ou seja, uma "ajuda" para se chegar a um fim: a reprodução simbólica e material da família. Ajudar é, assim, um verbo conjugado com mais frequência pelas mulheres e pode significar tanto "trabalhar" como "servir aos outros".

Desse modo, não é apenas uma coincidência o fato do microssistema pelo qual circulam dádivas provenientes da produção associada ao turismo na Chã de Jardim ter sido gerado sob uma liderança feminina, que sabe conjugar muito bem esse verbo e manipular a palavra "ajuda" em seus vários sentidos e acepções: remuneração, servir ao outro, apoio, trabalho, dom... Ratificando o argumento de que o que está em jogo na produção da oferta turística na Comunidade não é simplesmente o lucro ou relações mercantis. No caso estudado, parece existir uma relação de complementaridade entre as relações de mercado e a dinâmica da dádiva, disso resulta um sistema complexo em que uma lógica se serve da outra, ora tendendo para um lado, ora tendendo para o outro lado da balança, desenvolvendo-se um equilíbrio precário entre valores tradicionais e modernos. É certo que muitas vezes os vínculos sociais são privilegiados em detrimento da eficiência e da lucratividade, aspectos caros ao capitalismo. E em outras ocasiões, como na compra das galinhas diretamente dos produtores, não se pretende nada mais do que gerar economia e aumentar a lucratividade para o RVM, por exemplo.

É possivel aventar que a produção associada ao turismo e a criação do circuito de circulação de dádivas na Chã de Jardim é resultado de um modo feminino de trabalhar e de liderar, sendo a própria redistribuição dos rendimentos do turismo uma forma de justificar o trabalho das mulheres fora de casa, à medida que o trabalho delas mais uma vez coloca-se como

outras pesquisas de campo sobre os povos da Polinésia que mostram a prática generalizada de troca de presentes em sociedades não européias (LANNA, 2000). 
"ajuda", isto é, como a serviço do todo: a família / a comunidade, que, na concepção dos sitiantes, é hierarquicamente superior ao indivíduo.

O prazer de "ajudar", de trabalhar e de servir ao outro expressam a forma como as sitiantes se percebem e a posição que ocupam no espaço social. Como bem destacou Bourdieu (2006, p. 87), no artigo “O camponês e seu corpo", convém lembrar que "[...] o camponês é levado a introjetar a imagem que os outros fazem dele, mesmo quando se trata de um mero estereótipo". Seja produto de estereótipos ou de um habitus incorporado, servir aos outros parece ser percebido como uma qualidade naturalizada e uma característica identitária especialmente das mulheres sitiantes, referida como autêntica por elas mesmas e pelos turistas, clientes e visitantes.

As diferenças nas remunerações observadas entre os/as trabalhadores(as) diretos (fixos, diaristas e eventuais/avulsos) envolvidos nas atividades turísticas na Chã de Jardim devem-se aos diferentes tipos de relação e a posição que cada indivíduo ocupa no microssistema. Resgata-se, dessa forma, a premissa da teoria da dádiva de Marcel Mauss, segundo a qual o valor das coisas não pode ser superior ao valor da relação (MARTINS, 2005). A moral das dádivas, que estabelece a tripla obrigação de dar-receberredistribuir, parece ser, pois, tributária dos valores e do sistema hierárquico aos quais os sitiantes aderem e que tomam como referência na organização de seu modo de vida. No caso estudado, a contradição encontra-se no fato de que a formação do microsistema liderado pelas mulheres da comunidade é, simultaneamente, uma tentativa delas se auto-afirmarem pelo trabalho produtivo e também a reafirmação do papel delas na (re)produção dos valores comunitários, mais precisamente, do valor da reciprocidade como princípio legitimo das trocas entre os sitiantes.

Um outro aspecto não explorado dentro dessa discussão, mas tratado dentro da tese da autora, são os efeitos perversos do turismo e os aspectos obscuros das relações baseadas na reciprocidade. De um lado, merece atenção a exploração e a baixa remuneração dos trabalhadores. Do outro, deve-se lembrar que a reciprocidade característica da relação "patrão-cliente" inclui além de laços pessoais de dominação e subordinação, vínculos de parentesco que, sem dúvida, reforçavam o comprometimento e a lealdade 
(GRYNSZPAN, 1990). Nesse sentido, os trabalhadores do turismo na Comunidade estariam submetidos a uma dupla exploração, "já que há uma superposição de assimetrias capitalistas e não-capitalistas, um amalgamento entre dominação de classe e a desigualdade que é inerente à fundação sagrada da sociedade" (LANNA, 1995, p. 32).

Por outro lado, o trabalho para os sitiantes também é um meio para melhorar de vida, ver a família progredir e conquistar "dignidade", algo que se expressa no orgulho em poder consumir bens antes inacessiveis, graças ao próprio trabalho. Os rendimentos obtidos através do trabalho e da produção associada ao turismo são, portanto, uma forma de ter acesso ao "mundo dos bens". Sendo tais rendimentos desigualmente distribuidos, os sitiantes seguem mantendo o hábito de poupar para manter o fluxo de consumo estável ao longo do tempo, tal qual demonstrou Friedman (1957) apud Douglas (2007). E é no âmbito do consumo que os agentes parecem poder expressar sua individualidade, optando por bens pessoais que lhes diferenciam dentro da comunidade. Entretanto, o hábito de "ajudar" a família não é abandonado, realizando-se através de presentes (dons) para os pais e irmãos e em melhorias na casa da família.

De fato, entre as famílias dos sitiantes cada membro tem obrigação de "ajudar" (servir/trabalhar) a manter funcionando a unidade familiar, enquanto for dela dependente. E, mesmo que se torne independente, "o filho" terá uma divida impagável para com "os pais" e com sua família. O filho que não reconhece essa "divida" moral, é considerado pelos pais e pela comunidade como "ingrato", aludindo, portanto, a ideia de que expressar gratidão é algo positivado e que se materializa em presentes e contraprestações dirigidas aos pais/família.

É certo que a troca de dádivas define o funcionamento da Comunidade e influência/perturba até mesmo as trocas mercantis realizadas no âmbito dos serviços prestados aos turistas. Do fornecimento de artigos, em sistema de consignação, pelas artesãs e outros fornecedores à loja, passando pela realização de festas no RVM, sem contrato, tendo por garantia apenas "a palavra de quem encomendou, até a assistência mútua entre comunidades 
diferentes nas atividades lúdico-religiosas, a dádiva move as relações intra e intercomunitárias na Comunidade Chã de Jardim. De forma a transformar a relação entre trabalhadores e patrões, clientes e trabalhadores em um complexo circuito de trocas simbólicas, cujos elementos principais são: a confiança mútua, o respeito à hierarquia e ao princípio da reciprocidade.

\section{REFERÊNCIAS}

ALMEIDA, Horácio. Brejo de Areia. 2ed. João Pessoa: Editora Universitária/UFPB, 1980.

ALMEIDA, Mauro William Barbosa de. Redescobrindo a família rural. Revista Brasileira de Ciências Sociais. São Paulo. v.1, n. 1. p. 66-83, 1986. Disponivel em: <http://www.anpocs.org.br/portal/publicacoes/rbcs_00_01/rbcs01_06.htm. > Acesso: 10 set. 2016

ALMEIDA, Rosemeire Aparecida de. A sociologia da prática de Bourdieu e o campesinato. Revista Eletrônica da Associação dos Geógrafos Brasileiros. Seção Três Lagoas. Três Lagoas - MS, v. 1. n. ${ }^{\circ}$ 3. Ano 3, Maio de 2006. Disponivel em: <seer.ufms.br/index.php/RevAGB/article/dowloand/ 1348/863> Acesso em: 01 abr. 2017.

- (Re)criação do campesinato, identidade e distinção: a luta pela terra e o habitus de classe. São Paulo: Editora UNESP, 2006.

ALVES, Ângelo Guiseppe Chaves. Do "barro de loiça" à "loiça de barro": caracterização etnopedológica de um artesanato camponês no Agreste Paraibano. 2004. 197 f. Tese (Doutorado em Ciências Biológicas) Universidade Federal de São Carlos, São Carlos, 2004. Disponível em: < https://repositorio.ufscar.br/handle/ufscar/1757 > Acesso em: 03 out. 2017.

ALVES, Elder Patrick Maia. O consumo da tradição e a fruição do "inautêntico": cultura e mercado nas festas-espetáculo do ciclo juninos no Nordeste. Revista de Ciências Sociais. Fortaleza, v.48, n. 1, p.208-244, jan./jul., $2017 . \quad$ Disponivel em: <http:/ /www.periodicos.ufc.br/revcienso/article/view/18886/29617> Acesso em: 20 jun 2017.

A Economia Simbólica da Cultura Popular Sertanejo-Nordestina. Maceió: EDUFAL, 2011.

A economia simbólica da cultura popular sertanejo-nordestina. 2009. 385f. Tese (Doutorado em Ciências Sociais) - Universidade de Brasília, Departamento de Sociologia. Disponivel em: <http://repositorio.unb.br/handle/10482/4109>. Acesso em: 17 ago. 2016. 
APPADURAI, Arjun. Introdução: Mercadorias e a politica de valor. In: APPADURAI, Arjun (org.). A vida social das coisas: as mercadorias sob uma perspectiva cultural. Tradução de Agatha Bacelar. Niterói: Editora da Universidade Federal Fluminense, 2008 [1986].

AUlETE, Caldas. Minidicionário contemporâneo da lingua portuguesa. Rio de Janeiro: Nova Fronteira, 2004.

BÍBliA. Português. A Bỉblia: Tradução Ecumênica. Edições Loyola: São Paulo, 2002.

BOURDIEU, Pierre. Marginalia. Algumas notas adicionais sobre o dom. Mana [online]. vol.2, n.2, p.7-20. 1996. Disponivel em : $<$ www.scielo.br/scielo.php?script=sci_arttext\&pid=S0104-

$93131996000200001>$ Acesso em: 09 set. 2017.

. Célibat et condition paysanne. Études rurales. n5-6, 1962. pp. 32135. Disponivel em : https://www.persee.fr/doc/rural_00142182_1962_num_5_1_1011> Acesso em: 11 nov. 2016

A Dominação Masculina. Rio de Janeiro, Bertrand Brasil, 1999.

A Distinção - crítica social do julgamento. São Paulo: Edusp; Zouk, 2007 [1979].

. Meditações pascalianas. Tradução Sergio Miceli. Rio de Janeiro: Bertrand Brasil, 2001 [1997].

. Une classe objet. Actes de la recherche en sciences sociales. v. 1718, novembre 1977. (La paysannerie, une classe objet. pp. 2-5.) Disponível em : <http://www.persee.fr/doc/arss_0335-5322_1977_num_17_1_2572> Acesso em: 11 nov. 2016.

BRASIL. Ministério da Educação. EJA - Saberes da Terra (Apresentação). Secretaria de Educação Básica, 2017. Disponivel em:< http:/ / portal.mec.gov.br/pnaes / 194-secretarias-112877938/secadeducacao-continuada-223369541/18727-eja-saberes-da-terra > Acesso em: 16 mar. 2017.

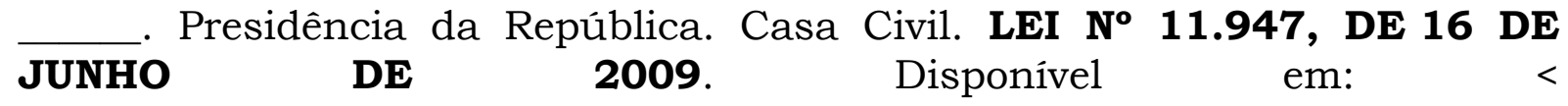
http:/ /www.planalto.gov.br/ccivil_03/_ato2007-

2010/2009/lei/111947.htm> Acesso em: 11 abr. 2017.

CHAYANOV, Alexander V. La organización de la unidad económica campesina. Buenos Aires: Nueva Visión, 1985 [1924].

CLASTRES, Pierre. A Sociedade Contra o Estado. Pesquisas de antropologia politica. Rio de Janeiro: Francisco Alves, 1978. 
CUCHE, Denys. A noção de cultura nas ciências sociais. Tradução de Viviane Ribeiro. 2ed. Bauru: EDUSC, 2002.

DOUGLAS, Mary; ISHERWOOD, Baron. O mundo dos bens: para uma antropologia do consumo. Rio de Janeiro: Editora UFRJ, 2006 [1979].

O mundo dos bens, vinte anos depois. Horizontes Antropológicos.

[online]. 2007, v.13, n.28, pp.17-32. Disponivel em: <http://www.scielo.br/scielo.php?pid=S010471832007000200002

\&script=sci_abstract > Acesso em: 26 jan. 2017.

GARCIA Jr., Afrânio Raul. O mundo social entre compartilhado e segmentado: relembrando os espaços de $\mathrm{O}$ Sul: caminho do roçado. Entrevista concedida à Patrícia Alves Ramiro. Politica \& Trabalho. Revista de Ciências Sociais, $n^{\circ} 45$, Julho/Dezembro de 2016, p. 375-393. Disponível em: periodicos.ufpb.br/index.php/politicaetrabalho/article/view/32914> Acesso em: 31 ago. 2017.

O Sul, Caminho do roçado: estratégias de reprodução camponesa e transformação social. São Paulo: Marco Zero, 1989.

GAVIRIA, Margarita Rosa; PEZZI, Silvane Maria. O poder simbólico da renda na mobilização social de jovens de comunidades rurais. In: MENASCHE, Renata (org.). Agricultura familiar à mesa: Saberes e práticas de alimentação no Vale do Taquari. Porto Alegre: Editora UFRGS, 2007.

GEERTZ, Clifford. A interpretação das Culturas. Rio de janeiro: LTC, 2008.

GONZÁLES, M. R. El turismo como nueva fuente de ingresos para el médio rural de Castilha y Léon. Cuadernos de Turismo, Murcia, n. 16, 2005, p. $175 \quad-\quad 195.12$ Disponivel : <http://revistas.um.es/turismo/article/view/18331/17691> Acesso em: 17 mar. 2017.

GUIGOU, Jacques. Problemas de uma sociologia da juventude rural. In: BRITTO, Sulamita de. (org.) Sociologia da Juventude. Rio de Janeiro: Zahar, 1968.

GRYNSZPAN, Mario. Os idiomas da patronagem: um estudo da trajetória de Tenório Cavalcanti. Revista Brasileira de Ciências Sociais, $\mathrm{n}^{\circ}$ 14, ano 5 , out./ 1990.

Disponivel

em:

<www.anpocs.org.br/portal/publicacoes/rbcs_00_14/rbcs14_07.htm>

Acesso em: 28 dez. 2017.

HEREDIA, Beatriz M. A. de. A morada da vida: trabalho familiar de pequenos produtores do Nordeste do Brasil. Rio de Janeiro: Paz e Terra, 1979.

JUNIOR, Jaime Santos; HASEGAWA, Aline Yuri. Migalhas de experiência: identidades e memórias a partir de dois estudos de caso. In: Ruris, Campinas/SP. V.11, N.01. p 113-150. mar, 2017. Disponivel em: 
https://www.ifch.unicamp.br/ojs/index.php/ruris/article/view/2909 Acesso em: 17 mai. 2018.

LANNA, Marcos P. D. Repensando a troca trobriandesa. Revista de Antropologia, $\mathrm{n}^{\mathrm{o}} 35$, S. Paulo, USP, 1992. Disponivel em: < https://www.revistas.usp.br/ra/article/view/111333> Acesso em: 23 nov. 2017.

A Divida Divina: troca e patronagem no Nordeste brasileiro. Campinas, SP: Editora da Unicamp, 1995.

Nota sobre Marcel Mauss e o Ensaio Sobre a Dádiva. Revista de Sociologia e Politica. n. ${ }^{\circ}$ 14: 173-194, jun. 2000. Disponivel em: < www.scielo.br/scielo.php?pid=S0104$44782000000100010 \&$ script=sci...tlng...> Acesso em: 21 set. 2017.

LUNARDI, Raquel. Mulher, turismo e desenvolvimento rural: o trabalho feminino na atividade turística. In: SANTOS, Eurico de Oliveira; SOUZA, Marcelino de. (orgs.). Teoria e prática do turismo no espaço rural. Barueri/SP: Manole, 2010.

MARTINS, José de Souza. A sujeição da renda da terra ao capital. (Encontros com a civilização brasileira, 22.) Rio de Janeiro: Civilização Brasileira, 1980.

Expropriação e violência: a questão política no campo. São Paulo: Hucitec, 1982.

MARTINS, Paulo Henrique. A Sociologia de Marcel Mauss: dádiva, simbolismo e associação. Revista Critica de Ciências Sociais, Coimbra, n. 73, p. 45-66, dez. 2005. Disponivel em: <https://rccs.revues.org/954> Acesso em: 12 jul. 2017.

MAUSS, Marcel. Marcel Mauss: Sociologia e Antropologia. Tradução de Paulo Neves. São Paulo: Cosac Nayfi, 2003.

MENDRAS, Henri. Sociedades camponesas. Rio de Janeiro: Zahar Editores, 1976.

PALMEIRA, Moacir. Casa e Trabalho: Nota sobre as relações sociais na plantation tradicional. 1977. In: WELCH, Clifford Andrew. et al. Camponeses brasileiros: leituras e interpretações clássicas, v.1. - São Paulo: Editora UNESP; Brasília, DF: Núcleo de Estudos Agrários e Desenvolvimento Rural, 2009 [1977].

PAULILO, M. I. Trabalho familiar: uma categoria esquecida de análise. Estudos Feministas, Florianopólis. v. 12, n. 1, Jan-abr. 2004, p. 229-252. Disponivel em: https://periodicos.ufsc.br/index.php/ref/article/view/S0104.../8696> Acesso em: 12 ago. 2011. 
PONGRATZ, Hans. Cultural Tradition and Social Change in Agriculture. Sociologia Ruralis. v. XXX-1, p. 5-17. 1990. Disponivel em: < https://pdfs.semanticscholar.org/.../b9a79544bef9b83a723027cee...> Acesso em: 28 mar. 2017.

SABOURIN, Éric. Práticas de reciprocidade e economia de dádiva em comunidades rurais do Nordeste brasileiro. Raizes, Ano XVIII, n. ${ }^{\circ}$ 20, novembro, 1999. $\quad$ pp. 41- 49. Disponivel em: <http://www.ufcg.edu.br/ raizes/artigos/Artigo_26.pdf > Acesso em: 12 abr. 2017.

SARTI, Cynthia Andersen. A família como espelho: um estudo sobre a moral dos pobres na periferia de São Paulo. 1994. 222f. Tese (Doutorado em Antropologia), Universidade de São Paulo, 1994. Disponivel em: < publicacoes.fcc.org.br/ojs/index.php/cp/article/download/808/818> Acesso em: 19 set. 2017.

SILVA, Luís. Casas de Campo: Etnografia do Turismo Rural em Portugal. Lisboa: ICS, 2009.

STRARHERN, Marilyn. O gênero da dádiva: problemas com as mulheres e problemas com a sociedade na Melanésía. Tradução de André Villalobos. Campinas, SP: Editora da UNICAMP, 2006.

TALAVERA, Agustín Santana. O rural como produto turístico: algo de novo brilha sob o sol? In:

SERRANO, Célia; BRUHNS, Heloísa Turini; LUCHIARI, M ${ }^{a}$ Tereza D. P. (orgs.). Olhares contemporâneos sobre o turismo. Campinas: Papirus, 2000, pp. 55-80.

Turismo Cultural, Culturas Turísticas. Horizontes Antropológicos, Porto Alegre, ano 9, n. 20, outubro de 2003. Disponivel em: < www.scielo.br/scielo.php?script=sci_arttext\&pid=S0104...> Acesso em: 07 dez. 2014.

WACQUANT, Loic. Seguindo Pierre Bourdieu no Campo. Rev. Sociol. Polit., Curitiba, 26, p. 13-29, jun. 2006. Disponivel em: < www.scielo.br/pdf/rsocp/n26/a03n26.pdf> Acesso em: 04 mai. 2016.

WEBER, Max. Ensaios de Sociologia. LTC: Rio de Janeiro, 1982 [1946].

A Ética Protestante e o Espirito do Capitalismo. 5 ed. São Paulo: Pioneira, 1987 [1904/1905].

WOLF, Eric. Sociedades Camponesas. Curso de Antropologia Moderna. Rio de Janeiro, Zahar Editores, 1970.

WOORTMANN, Klass. Com parentes não se negoceia: o campesinato como ordem moral. Anuário Antropológico/87. Brasília: Editora da Universidade de Brasilia, 1990. Disponivel em: < 
www.dan.unb.br/images/pdf/anuario_antropologico/.../anuario87_woortma nn.pdf> Acesso em: 11 set. 2016.

A transformação da subordinação. In: CARDOSO DE OLIVEIRA, R. (Org). Anuário Antropológico. Edições: Universidade Federal do Ceará; Fortaleza e Tempo Brasileiros: Rio de Janeiro, n. 81, p. 204-229, 1983.

WOORTMANN, Ellen F. Padrões tradicionais e modernização: comida e trabalho entre camponeses teuto-brasileiros. In: MENACHE, Renata (org.). Agricultura familiar à mesa: Saberes e práticas de alimentação no Vale do Taquari. Porto Alegre: Editora UFRGS, 2007.

. O Sítio Camponês. Anuário Antropológico/81. Edições Tempo Brasileiro. Rio de Janeiro, 1982/83. Disponivel em www.dan.unb.br/images/pdf/anuario.../anuario81_ellenwoortmann.pdf

Acesso em: 18 mar. 2017.

Da complementaridade à dependência: espaço, tempo e gênero em 'comunidades pesqueiras' do Nordeste. Série Antropologia. Brasília, 1991. Disponivel em: <http://dan.unb.br/images/doc/Serie111empdf.pdf > Acesso em: 08 out. 2017.

YÚDICE, George. E1 Recurso de la Cultura: Usos de la cultura en la era global. Editorial Gedisa: Barcelona, 2002. 